\title{
Égerlápok a Tengelici-homokvidéken (Carici elongatae-Alnetum glutinosae W. Kосн 1926)
}

\author{
KEVEY BALÁZS ${ }^{1}$ és TÓTH ISTVÁN ZSOLT² \\ 1: Pécsi Tudományegyetem Ökológiai Tanszék, H-7624 Pécs, Ifjúság u. 6., e-mail: keveyb@gamma.ttk.pte.hu \\ 2: H-7150 Bonyhád, Kossuth L. u. 23., e-mail: tizs@citromail.hu
}

\begin{abstract}
KeVEY, B. \& Tóth, I. Zs.: Alder swamps in the Tengelic Sand Ridge.

Abstract: The study contains a phytosociological analysis of alder swamps found in the Tengelic Sand Ridge, an expanse of mostly windblown sand in the westernmost part of the Great Hungarian Plain, west of the Danube River. These swamps occur in the depressions among sand dunes, where the ground is covered with water for most part of the year. The species composition is characterized by the dominance of alder (Alnus glutinosa) in the forest canopy with the sporadic occurrence of common birch (Betula pendula). The stands also host several rare herbaceous species, some of which are considered relics in the Great Plain, such as Carex paniculata, C. pseudocyperus, Cirsium palustre, Dryopteris carthusiana, D. dilatata, D. expansa, Listera ovata, Thelypteris palustris, Urtica kioviensis, , and Veratrum album.
\end{abstract}

Keywords: Great Hungarian Plain, forest vegetation on sand, syntaxonomy

\section{Bevezetés}

Az egykori alföldi lápvilág hírmondóit a Tengelicihomokvidéken ma már csak néhány parányi folt képviseli. llyenek az égerlápok (Carici elongatae-Alnetum glutinosae). Mivel állományaikat eddig nem vizsgálták, jelen tanulmánnyal e hiányt szeretnénk pótolni. E láperdők jövőjét bizonytalannak látjuk, s félő, hogy néhány évtized multán megsemmisülnek, vagy legalábbis jelentősen átalakulnak. A jövőben így cönológiai felvételeink tanúskodhatnak arról, hogy milyen volt a Tengelici-homokvidék égerlápjainak faji összetétele az ezredforduló tájékán.

\section{Anyag és módszer}

\subsection{Kutatási terület jellemzése}

A Tengelici-homokvidék meszes homokból épül fel. Az eredeti növénytakaróból igen kevés erdő maradt meg (BoRos 1953, 1959; KeVEY 2015; KeVEY és LENDVAl 2015). A homokbuckák közötti mélyebb termőhelyeken néhol még megmaradtak az égerlápok, amelyek gyepszintje az év jelentős részében vízzel borított. Tőzeges láptalajon fejlődnek. Állományaikat néhol kiszáradó égerlápok (Molinio-Alnetum glutinosae), másutt zárt homoki tölgyesek (Polygonato latifolii-Quercetum roboris) szegélyezik (1. ábra).

\subsection{Alkalmazott módszerek}

A cönológiai felvételek a Zürich-Montpellier növénycönológiai iskola (BECKING 1957, BRAUN-BLANQUET 1964) hagyományos kvadrát-módszerével készültek.
A felvételek táblázatos összeállítása, valamint a karakterfajok csoportrészesedésének és csoporttömegének számítása az „NS” számítógépes programcsomaggal (KeVEY és HIRMANN 2002) történt. A felvételkészítés és a hagyományos statisztikai számítások - kissé módosított - módszere KEVEY (2008) tanulmányában megtalálható. A SYN-TAX 2000 program segítségével (PODANI 2001) sokváltozós elemzéseket is végeztünk. E téren részben bináris cluster-analízist (Method: Complete link; Coefficient: Baroni-Urbani és Buser), és szintén bináris ordinációt (Method: principal coordinates analysis; Coefficient: Baroni-Urbani és Buser) alkalmaztunk.

A fajok esetében KIRÁLY (2009), a társulásoknál pedig BORHIDI és KEVEY (1996), BORHIDI és mtsai (2012), ill. KEVEY (2008) nómenklatúráját követjük. A társulástani és a karakterfaj-statisztikai táblázatok felépítése az újabb eredményekkel (OBERDORFER 1992; MucINA és mtsai 1993; BoRHIDI és mtsai 2012; KEVEY 2008) módosított Soó (1980) féle cönológiai rendszerre épül. A növények cönoszisztematikai besorolásánál is elsősorban Soó (1964, 1966, 1968, 1970, 1973, 1980) Synopsis-ára támaszkodtunk, de figyelembe vettük az újabb kutatási eredményeket is (vö. BoRHIDI 1993, 1995; HoRVÁtH F. és mtsai 1995; KEVEY ined.).

\section{Eredmények}

\subsection{Fiziognómia}

A vizsgált zárt lösztölgyesek felső lombkoronaszintje az állomány korától és a termőhelyi viszonyoktól függően 15-25 m magas, borítása pedig 50-75\%. Állandó (K: V) és egyben állományalkotó (A-D: 3-4) fája csak az Alnus glutinosa. Ahol a felső koronaszint ritkább, a lékeket alacsonyabb fák igyekeznek elzárni. Az alsó lombkoronaszint magassága 10-18 m, míg borítása 5-40\%. Állandó (K: IV) és helyenként nagyobb tömegben (A-D: 3) előforduló fája itt is csak az Alnus glutinosa.

A cserjeszint fejlettsége igen változó. Magassága 1,5-3 $\mathrm{m}$, borítása pedig 5-50\%. Állandó (K: V) elemei a következők: Alnus glutinosa, Cornus sanguinea, Frangula alnus, Salix cinerea. E szintben nagyobb tömeget (A-D: 3) csak az idegenhonos Fraxinus pennsylvanica ér el. $\mathrm{Az}$ alsó cserjeszint (újulat) fejletlen (1-10\%). Állandó (K: IV-V) fajai az alábbiak: Cornus sanguinea, Frangula alnus, Rubus caesius, Viburnum opulus. E szintben fáciesképző szerepet egyetlen faj sem játszik.

A gyepszint borítása igen változó (20-90\%). Állandó elemei (K: IV-V) a következök: Bidens tripartita, Calystegia sepium, Carex acutiformis, Carex elata, Carex 

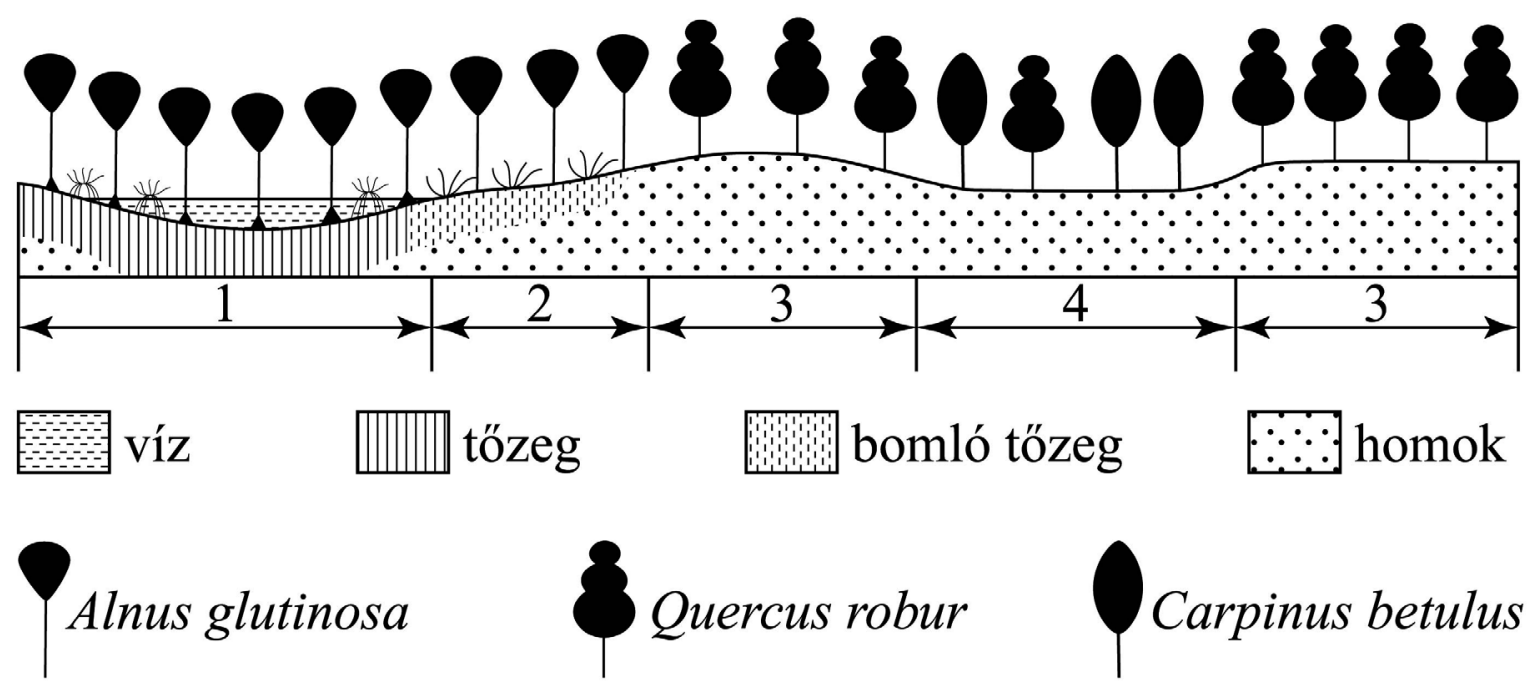

Wolinia hungarica

* Carex elata

1. ábra. Vegetáció-keresztmetszet a Németkér melletti „Barát-erdő”-ből (KEVEY 2008).

1: égerláp (Carici elongatae-Alnetum glutinosae); 2: kiszáradó égerláp (Molinio-Alnetum glutinosae);

3: gyöngyvirágos-tölgyes (Polygonato latifolii-Quercetum roboris); 4: homoki gyertyános-tölgyes (Convallario-Carpinetum).

pseudocyperus, Carex riparia, Deschampsia caespitosa, Dryopteris carthusiana, Equisetum arvense, Eupatorium cannabinum, Galium palustre, Humulus lupulus, Iris pseudacorus, Lycopus europaeus, Lysimachia vulgaris, Lythrum salicaria, Poa palustris, Ranunculus repens, Rorippa amphibia, Scrophularia nodosa, Scutellaria nodosa, Solanum dulcamara, Solidago gigantea, Stachys palustris, Thelypteris palustris, Urtica kioviensis. A gyepszintben csak a Carex acutiformis és a Carex elata jut fáciesképző szerephez.

\subsection{Fajkombináció}

\subsection{1. Állandósági osztályok eloszlása}

A 40 cönológiai felvétel alapján a vizsgált zárt lösztölgyesekből 18 konstans ( $\mathrm{K}$ V) és 16 szubkonstans (K IV) faj szerepel az alábbiak szerint: K V: Alnus glutinosa, Carex acutiformis, Carex elata, Carex riparia, Cornus sanguinea, Deschampsia caespitosa, Frangula alnus, Galium palustre, Humulus lupulus, Iris pseudocorus, Lysimachia vulgaris, Lythrum salicaria, Ranunculus repens, Rubus caesius, Salix cinerea, Solanum dulcamara, Stachys palustris, Urtica kioviensis. - K IV: Bidens tripartita, Calystegia sepium, Carex pseudocyperus, Crataegus monogyna, Dryopteris carthusiana, Equisetum arvense, Eupatorium cannabinum, Fraxinus excelsior, Lycopus europaeus, Poa palustris, Rorippa amphibia, Scrophularia nodosa, Scutellaria galericulata, Solidago gigantea, Thelypteris palustris, Viburnum opulus. A társulásból továbbá 31 akcesszórikus (K III), 21 szubakcesszórikus (K II) és 66 akcidens (K I) faj került elő (vö. 1. táblázat). Az állandósági osztályokat tekintve tehát az akcidens (K I) és a konstans ( $\mathrm{K}$ V) elemek mellett az akcesszórikus (K III) fajoknál is mutatkozik egy kiugrás.

\subsubsection{Karakterfajok aránya}

A vizsgált égerlápok karakterét elsősorban az Alnetea glutinosae s.l. fajok adják, amelyek csoportrészesedése $12,8 \%$, csoporttömege pedig 23,6\%: $\mathrm{K}$ V: Alnus glutinosa, Salix cinerea. - K IV: Carex pseudocyperus, Dryopteris carthusiana, Thelypteris palustris. - K III: Calamagrostis canescens. - $\mathrm{K} \mathrm{I}$ : Dryopteris dilatata, Dryopteris expansa.

Jelentős szerepet játszanak a Phragmitetea s.I. elemek is, $17,6 \%$ csoportrészesedéssel és $16,5 \%$ csoporttömeggel: K V: Carex acutiformis, Carex elata, Carex riparia, Galium palustre, Iris pseudacorus, Solanum dulcamara, Stachys palustris, Urtica kioviensis. - K IV: Lycopus europaeus, Eupatorium cannabinum, Rorippa amphibia, Poa palustris, Scutellaria galericulata. K III: Carex paniculata, Cirsium palustre, Glyceria plicata, Oenanthe aquatica, Phragmites australis, Teucrium scordium. - K II: Alisma plantago-aquatica, Glyceria maxima, Sparganium erectum, Veronica catenata. - K I: Alisma lanceolatum, Carex vesicaria, Carex otrubae, Epilobium hirsutum, Epilobium parviflorum, Euphorbia palustris, Glyceria fluitans, Hypericum tetrapterum, Myosotis nemorosa, Phalaris arundinacea, Schoenoplectus lacustris, Scrophularia umbrosa, Typha angustifolia.

Figyelemre méltó a Molinio-Juncetea s.I. fajok jelenléte is, amelyek $8,1 \%$ csoportrészesedést és $6,7 \%$ csoporttömeget mutatnak: K V: Deschampsia caespitosa. - K III: Angelica sylvestris, Valeriana dioica, Valeriana officinalis, Veratrum album. - K II: Filipendula ulmaria, Symphytum officinale. - K I: Molinia coerulea, Selinum carvifolia.

Egyes elemek Alnion incanae jelleggel is rendelkeznek, így e szüntaxon 9,5\% csoportrészesedést és $30,6 \%$ csoporttömeget ér el: K V: Frangula alnus. 


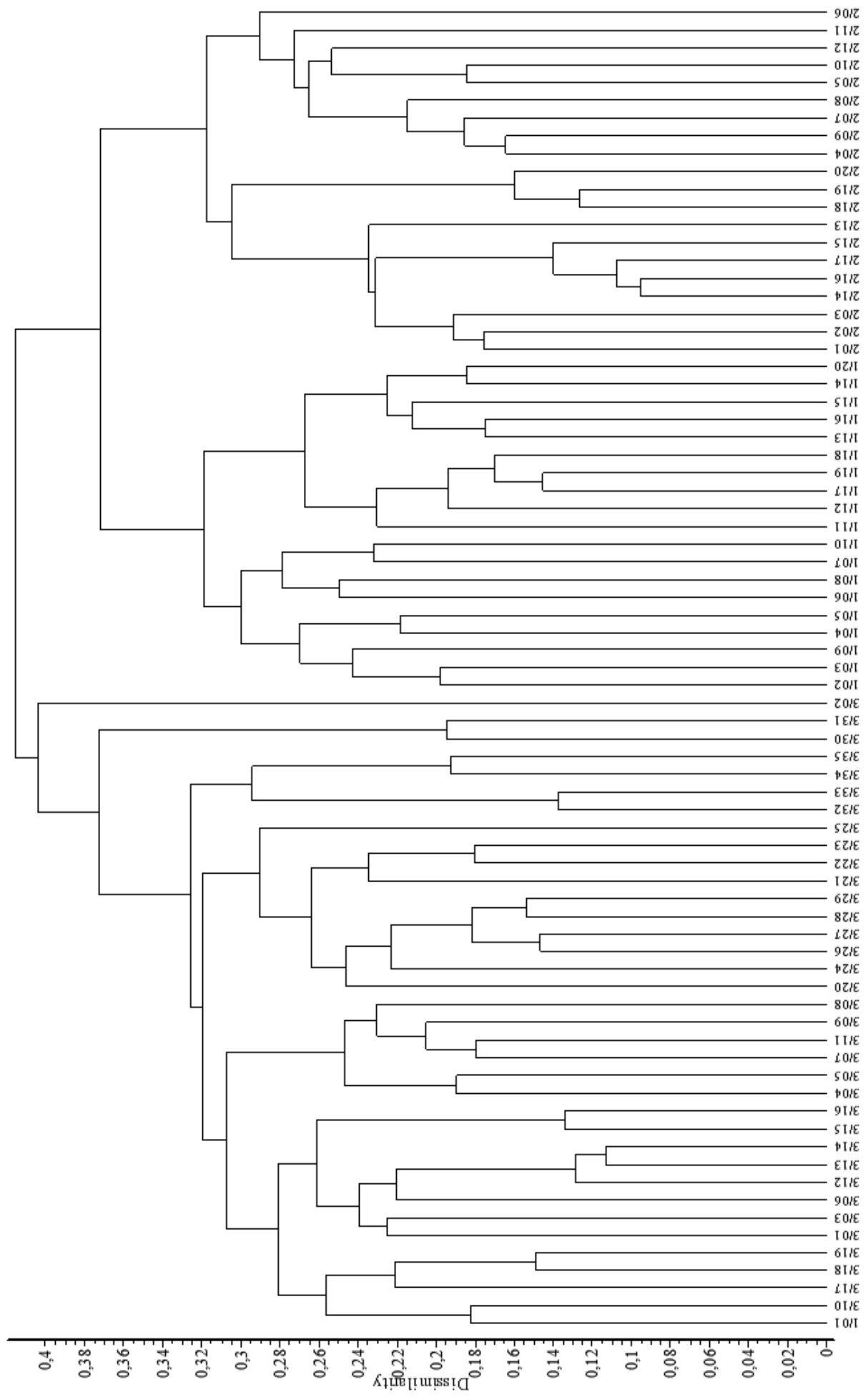

2. ábra. Égerlápok bináris dendrogramja

(Method: Group average, Coefficient: Baroni-Urbani-Buser)

1/1-20: Carici elongatae-Alnetum glutinosae, Tengelici-homokvidék (KEVEY és TótH ined.)

2/1-20: Carici elongatae-Alnetum glutinosae, Szigetköz (KEVEY és ALEXAY ined.)

3/1-35: Carici elongatae-Alnetum glutinosae, Belsö-Somogy (KEVEY és CSETE ined.) 


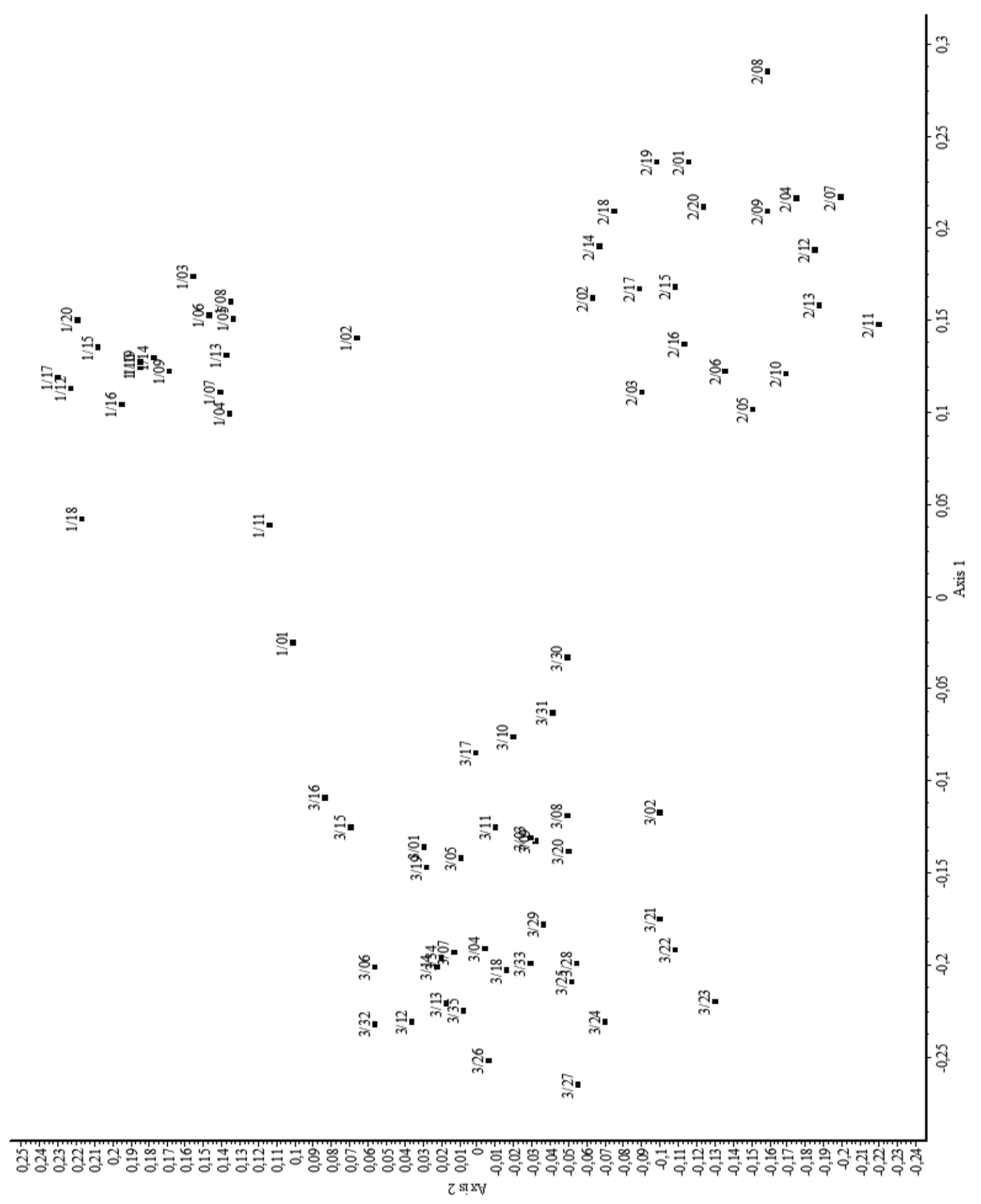

3. ábra. Égerlápok bináris ordinációs diagramja

(Method: Principal coordinates analysis, Coefficient: Baroni-Urbani-Buser)

1/1-20: Carici elongatae-Alnetum glutinosae, Tengelici-homokvidék (KEVEY és TótH ined.)

2/1-20: Carici elongatae-Alnetum glutinosae, Szigetköz (KEVEY és ALEXAY ined.)

3/1-35: Carici elongatae-Alnetum glutinosae, Belsö-Somogy (KEVEY és CSETE ined.) 
- K IV: Viburnum opulus. - K III: Festuca gigantea, Ribes rubrum. - K II: Populus alba. - $\mathrm{K} \mathrm{I}$ : Elymus caninus, Malus sylvestris, Padus avium.

A higrofil fajok jelentős része Salicetea purpureae s.l. jelleget is mutat, ezért e szüntaxon 9,2\% csoportrészesedést és $5,8 \%$ csoporttömeget mutat. Némi szerepet játszanak még egyes higrofil ruderáliák, mint a Galio-Urticetea s.I. és a Bidentetea s.I. elemek.

Összehasonlítva a Tengelici-homokvidék, a Szigetköz és a Belső-Somogy égerlápjait, azt tapasztaljuk, hogy a fenti fontosabb paraméterek arányában igen nagy a hasonlóság (lásd: 1 . és 3. táblázat).

\subsubsection{Sokváltozós statisztikai elemzések eredményei}

A Tengelici-homokvidék, a Szigetköz és a Belső-Somogy égerlápjait sokváltozós elemzésekkel is összehasonlítottuk. Mind a dendrogramon (2. ábra), mind az ordinációs diagramon (3. ábra) a cönológiai felvételek a három földrajzi tájnak megfelelően három csoportba tömörülnek, amelyek egymáshoz viszonylag közel helyezkednek el. Némi kivételt képez a Tengelici-homokvidék 1. számú felvétele, amely a dendrogramon (2. ábra) Belsö-Somogy felvételei közé került, az ordinációs diagramon (3. ábra) pedig a Tengelici-homokvidék és Belső-Somogy felvételei között helyezkedik el.

\section{Megvitatás}

A Tengelici-homokvidék égerlápjai igen hasonló termőhelyi viszonyok mellett jöttek létre, mint Magyarország egyéb égerlápjai. Ennek következtében faji összetételük is igen hasonlít a szigetközi és belső-somogyi égerlápokéhoz. Egyes karakterfajok arányát tekintve azonban viszonylag nagyobb különbségek mutathatók ki a Tengelici-homokvidék és a Belső-Somogy égerlápjai között (3. táblázat). Így Belső-Somogy homokvidékének égerlápjaiből mintegy háromszor annyi Fagetalia fajt sikerült kimutatni, mint a Tengelici-homokvidéken. A Quercetea pubescentis-petraeae elemek esetében viszont ezen arány fordítottját kaptuk. Ennek magyarázata nagyrészt klimatikai tényezőkben keresendő (vö. BORHIDI 1961). Ugyanis a gyertyános-tölgyes övbe tartozó Belső-Somogy égerlápjai nagyrészt gyertyános-tölgyesekkel (Fraxino pannonicae-Carpinetum), az erdőssztyep zónába sorolható Tengelici-homokvidék égerlápjai pedig elsősorban gyöngyvirágos-tölgyesekkel (Polygonato latifolii-Quercetum roboris) érintkeznek. E szomszédos erdőtársulások fajai ha nem is játszanak meghatározó szerepet az égerlápok felépítésében, de némileg bekerülnek az égerlápok magasabban fekvő részeibe, így képesek megtelepedni az égerfák vízszintből kiemelkedő gyökérfőin.

$A z$ állandósági osztályok eloszlásánál zavaróan hat, hogy a konstans ( $\mathrm{K} V$ ) és az akcidens ( $\mathrm{K} \mathrm{I}$ ) fajok között az akcesszórikus (K III) elemeknél is jelentkezik egy harmadik kiugrás, amely feltételez egy viszonylagos heterogenitást. Mindez a fragmentációjával és az izolációval hozható összefüggésbe.

Fenti vizsgálati eredmények szerint a Tengelicihomokvidék égerlápjai nem különülnek el lényegesen sem a Szigetköz, sem pedig a Belső-Somogy égerlápjaitól, ezért a Carici elongatae-Alnetum glutinosae aszszociációval azonosíthatók, amelynek helye a növénytársulások rendszerében az alábbi módon vázolható:

\section{Divízió: Q U E R C O - F A G E A JAKUcs 1967}

Osztály: ALNETEA GLUTINOSAE BR.-BL. et Tx. ex WESTHOFF et al. 1946

Rend: ALNETALIA GLUTINOSAE Tx. 1937

Csoport: Alnion glutinosae MALCUIT 1929

Alcsoport: Carici elongatae-Alnenion glutinosae KEVEY 2008

Társulás: Carici elongatae-Alnetum glutinosae W. KocH 1926

\section{Természetvédelmi vonatkozások}

A Tengelici-homokvidék égerlápjait eddig alig kutatták, ezért természetvédelmi értékeikről szinte mit sem tudtunk. A vizsgált állományok fele a Németkérnél levő „Fekete-tó” szegélyén található, másik fele pedig az ettől északra elterülő „Barát-erdő” három különböző pontján van. Ezen égerlápok állapota természetvédelmi szempontból egyelöre jónak mondható. $E$ helyeken kívül a homokvidéken többfelé is találhatók mára jellegtelenné váló égeresek, amelyek valószínüleg a talajvízszint csökkenésével párhuzamosan váltak fajszegénnyé. Félő, hogy a még jó állapotú égerlápok is egy idő után hasonló sorsra jutnak.

Felméréseink során az égerlápokból hét védett növényfaj került elő: $\mathrm{K}$ V: Urtica kioviensis. - $\mathrm{K}$ IV: Dryopteris carthusiana, Thelypteris palustris. - K III: Veratrum album. - K I: Dryopteris dilatata, Dryopteris expansa, Listera ovata. E növények között különös értéket képvisel az országosan ritka Urtica kioviensis és a Dryopteris expansa.

Flóraszennyező hatást fejtenek ki egyes tájidegen fásszárú és lágyszárú növények: K IV: Solidago gigantea. - K III: Fraxinus pennsylvanica. - $\mathrm{K}$ I: Acer negundo, Asclepias syriaca, Aster salignus, Celtis occidentalis, Erigeron canadensis, Gleditsia triacanthos, Robinia pseudo-acacia, Vitis riparia. Közülük egyelöre csak a Solidago gigantea és a Fraxinus pennsylvanica fejt ki némi zavaró hatást. Utóbbi faj borítási értékei helyenként eléggé nagyok, így félő, hogy ezen égerlápokban erősen el fog terjedni. Visszaszorítását a termő egyedek kivágásával kellene kezdeni.

Az elmúlt pár évtizedben sikerült megfigyelnünk azt, hogy az 1982-től 1995-ig tartó rendkívül csapadékszegény években a vizsgált égerlápokban eltűnt a víztükör, a gyepszintben pedig igen elszaporodott az Urtica dioica. A száraz periódust azonban erősen csapadékos évek követték, s ekkor helyreállt a korábbi egyensúly, s az Urtica dioica is visszaszorult.

A 1999-ben jött létre a Dél-Mezőföld Tájvédelmi Körzet, amelyben a vizsgált égerlápok fokozott védelemben részesülnek. Így talán megvan a remény arra, hogy e parányi láperdőket megmenthetjük az utókor számára. 


\section{Rövidítések}

A1: felső lombkoronaszint; A2: alsó lombkoronaszint; Agi: Alnenion glutinosae-incanae; Ai: Alnion incanae; Alo: Alopecurion pratensis; Aon: Alnion glutinosae; APa: Abieti-Piceea; AQ: Aceri tatarici-Quercion; Ar: Artemisietea; Ate: Alnetea glutinosae; B1: cserjeszint; B2: újulat; Bec: Beckmannion eruciformis; Ber: Berberidion; Bia: Bidentetea; Bin: Bidention tripartiti; C: gyepszint; Cal: Calystegion sepium; Ccn: Caricion canescentinigrae; Cgr: Caricenion gracilis; Che: Chenopodietea; Chr: Chenopodion rubri; ChS: Chenopodio-Scleranthea; CM: Cardamini-Montion; Cp: Carpinenion betuli; Cro: Caricenion rostratae; CyF: Cynodonto-Festucenion; Des: Deschampsion caespitosae; Epa: Epilobietea angustifolii; Epn: Epilobion angustifolii; F : Fagetalia sylvaticae; FiC: Filipendulo-Cirsion oleracei; FPe: Festuco-Puccinellietea; FPi: Festuco-Puccinellietalia; Fvg: Festucetea vaginatae; GA: Galio-Alliarion; HyL: Hydrochari-Lemnetea; ined.: ineditum (kiadatlan közlés); Le: Lemnion minoris; LeP: Lemno-Potamea; Mag: Magnocaricetalia; Moa: Molinietalia coeruleae; MoA: Molinio-Arrhenatherea; MoJ: Molinio-Juncetea; Mon: Molinion coeruleae; Nc: Nanocyperion flavescentis; NG: Nasturtio-Glycerietalia; Ory: Oryzetea sativae; Pea: Potametea; Pla: Plantaginetea; Pli: Phragmitetalia;
Pna: Populenion nigro-albae; PQ: Pino-Quercetalia; Prf: Prunion fruticosae; Pru: Prunetalia spinosae; Pte: Phragmitetea; Qc: Quercetalia cerridis; QFt: QuercoFagetea; Qpp: Quercetea pubescentis-petraeae; Qr: Quercetalia roboris; S: summa (összeg); Sal: Salicion albae; SCn: Scheuchzerio-Caricetea nigrae; Sea: Secalietea; s.l.: sensu lato (tágabb értelemben); Spu: Salicetea purpureae; Str: Salicion triandrae; TA: Tilio platyphyllae-Acerenion pseudoplatani; Ulm: Ulmenion; US: Urtico-Sambucetea; VP: Vaccinio-Piceetea.

\section{Összefoglalás}

Jelen tanulmány a Magyar-Alföld nyugati peremén levő Tengelici-homokvidék égerlápjainak (Carici elongataeAlnetum glutinosae) cönológiai elemzését tartalmazza 20 felvétel alapján. Állományai a homokbuckák közötti mélyebb termőhelyeken fordulnak elö, amelyek az év jelentős részében vízzel borítottak. E láperdők az Alföldön egykor jóval gyakoribb lápvilágról tanúskodnak. Állományaikban ritkaságnak számító növényfajok is előfordulnak: Carex paniculata, Carex pseudocyperus, Cirsium palustre, Dryopteris carthusiana, Dryopteris dilatata, Dryopteris expansa, Listera ovata, Thelypteris palustris, Urtica kioviensis, Veratrum album.

\section{Irodalom}

BECKING, R. W. 1957: The Zürich-Montpellier Schol of phytosociology. - Botanical Review 23: 411-488.

BoRHIDI, A. 1961: Klimadiagramme und klimazonale Karte Ungarns. - Annales Universitatis Scientiarum Budapestinensis, Sectio Biologica 4: 21-250.

BoRHIDI, A. 1993: A magyar flóra szociális magatartás típusai, természetességi és relatív ökológiai értékszámai. - Janus Pannonius Tudományegyetem, Pécs, 95 pp.

BORHIDI, A. 1995: Social behaviour types, the naturalness and relative ecological indicator values of the higher plants in the hungarian flora. - Acta Botanica Academiae Scientiarum Hungaricae 39: 97-181.

BORHIDI, A. \& KEVEY, B. 1996: An annotated checklist of the hungarian plant communities II. - In: BORHIDI, A.: Critical revision of the hungarian plant communities. Janus Pannonius University, Pécs, pp. 95-138.

Borhidi, A., KeVEy, B. \& Lendval, G. 2012: Plant communities of Hungary. - Akadémiai Kiadó, Budapest, 544 pp.

Boros, Á. 1953: A Mezőföld növényföldrajzi vázlata. - Földrajzi Értesítő 2: 234-253.

Boros, Á. 1959: A Mezőföld növényföldrajza. - In: Ádám, L. - Marosi, S. - Szilárd, J.: A Mezőföld természeti földrajza. Akadémiai Kiadó, Budapest, pp. 363-383.

Braun-Blanquet, J. 1964: Pflanzensoziologie (ed. 3.). - Springer Verlag, Wien-New York, 865 pp.

HoRvÁth, F., Dobolyl, Z. K., MORSchHAuSER, T., LöKÖS, L., KARAS, L. és SzERDAHELYI, T. 1995: Flóra adatbázis 1.2. - MTA Ökológiai és Botanikai Kutatóintézete, Vácrátót, 267 pp.

JAKUCS, P. 1967: Gedanken zur höheren Systematik der europäischen Laubwälder. - Contribuţii Botanice, Cluj 1967: 159-166.

KEVEY, B. 2008: Magyarország erdőtársulásai (Forest associations of Hungary). Die Wälder von Ungarn. - Tilia 14: 1-488. + CD-adatbázis (244 ábra + 230 táblázat)

KEVEY, B. 2015: A Tengelici-homokvidék zárt homoki tölgyesei (Polygonato latifolii-Quercetum roboris BORHIDI in BORHIDI et KEVEY 1996). - Natura Somogyiensis 27: 5-36.
KEVEY, B. és HIRMANN, A. 2002: „NS” számítógépes cönológiai programcsomag. - In: Aktuális flóra- és vegetációkutatások a Kárpát-medencében V. Pécs, 2002. március 8-10. (Összefoglalók), pp. 74.

KeVEY, B. és LendVAI, G. 2015: A Tengelici-homokvidék gyertyános-tölgyesei (Convallario-Carpinetum KEVEY 2008). - Natura Somogyiensis 26: 5-37.

KIRÁLY, G. (szerk.) 2009: Új magyar füvészkönyv. Magyarország hajtásos növényei. Határozókulcsok. - Aggteleki Nemzeti Park Igazgatóság, Jósvafö, 616 pp.

$\mathrm{KoCH}$, W. 1926: Die Vegetationseinheiten der Linthebene unter Berücksichtigung der Verhältnisse in der Nordostschweiz. Jahrbuch der St. Gallische Naturwissenschaftliche Gesellschaft 61: 1-134.

MALCUIT, G. 1929: Les associations végétales de la Vallée de la Lanterne. - Archives de Botanique, Mémoires. Caen. 2: 142-154.

Mucina, L., Grabherr, G. \& Wallnöfer, S. 1993: Die Pflanzengesellschaften Österreichs III. Wälder und Gebüsche. - Gustav Fischer, Jena-Stuttgart-New York, 353 pp.

OBERDORFER, E. 1992: Süddeutsche Pflanzengesellschaften IV. A Textband. - Gustav Fischer Verlag, Jena-Stuttgart-New York, 282 pp.

PODANI, J. 2001: SYN-TAX 2000 Computer Programs for Data Analysis in Ecologi and Systematics. - Scientia, Budapest, $53 \mathrm{pp}$

Soó, R. 1964, 1966, 1968, 1970, 1973, 1980: A magyar flóra és vegetáció rendszertani-növényföldrajzi kézikönyve I-VI. - Akadémiai kiadó, Budapest.

TÜXEN, R. 1937: Die Pflanzengesellschaften Nordwestdeutschlands. Mitteilungen der Floristisch-Soziologischen Arbeitsgemeinschaft Niedersachsen, Hannover 3: 1-170.

Westhoff, V., DiJK, J.W., PAsschier, H. \& Sissing, G. 1946: Overzicht der plantengemeen schappen in Nederland (2e druk). - G. W. Breughel, Amsterdam, 118 pp. 


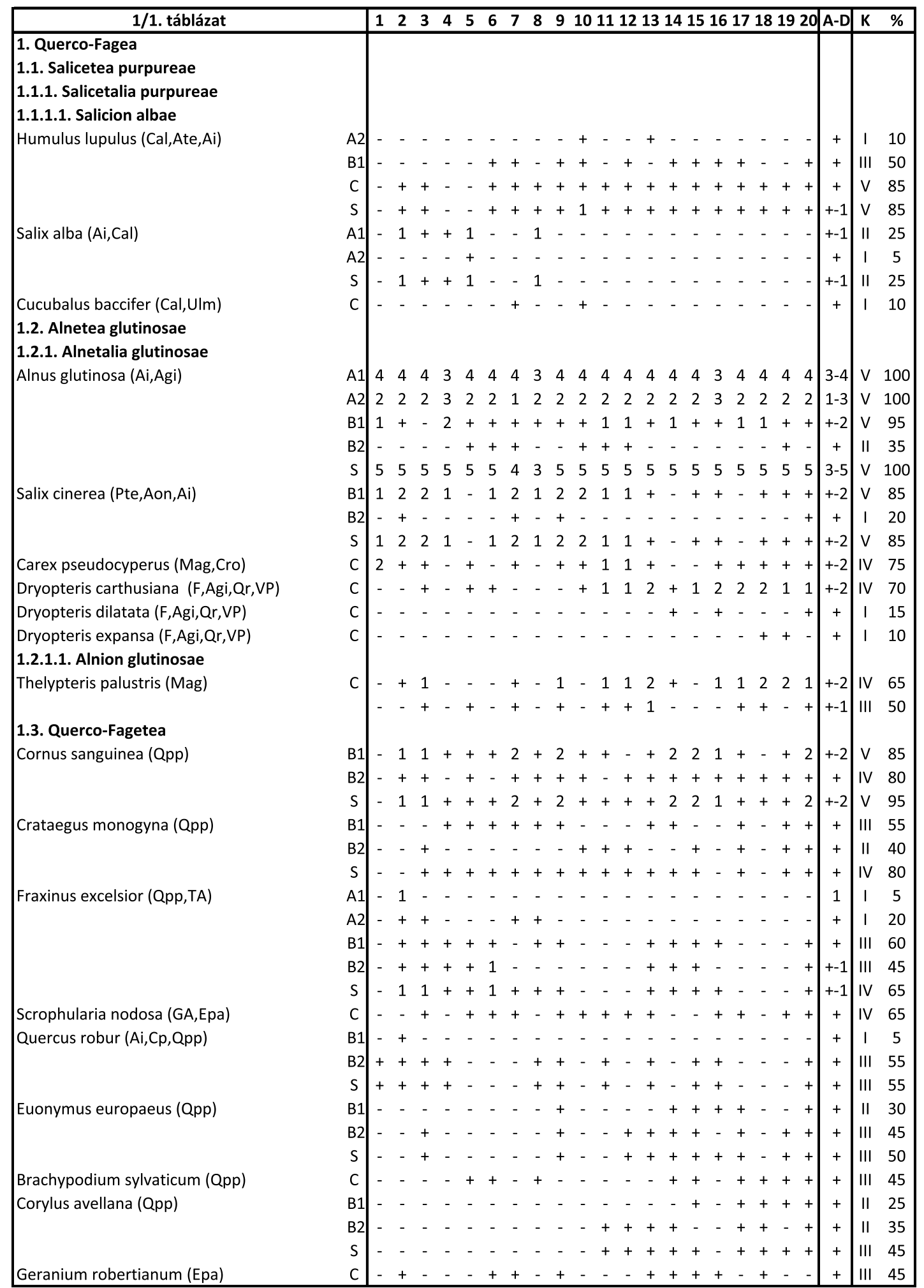




\begin{tabular}{|c|c|c|c|c|c|c|c|c|c|c|c|c|c|c|c|c|c|c|c|c|c|c|c|c|}
\hline 1/2. táblázat & & 1 & 2 & 3 & 4 & 5 & 6 & 7 & 8 & 9 & & 11 & & & & & & & & & & $A-D$ & $\mathbf{K}$ & $\%$ \\
\hline \multirow[t]{3}{*}{ Rhamnus catharticus (Qpp,Pru) } & B1 & - & - & - & - & - & - & - & - & + & + & - & + & + & - & + & + & - & - & - & - & + & II & 30 \\
\hline & B2 & - & - & + & - & - & - & - & + & - & - & - & - & + & + & + & - & - & - & - & - & + & II & 25 \\
\hline & $\mathrm{s}$ & - & - & + & - & - & - & - & + & + & + & - & + & + & + & + & + & - & - & - & - & + & III & 45 \\
\hline Mycelis muralis & $\mathrm{C}$ & - & + & - & - & - & + & - & + & - & - & - & - & + & + & + & + & - & - & - & - & + & II & 35 \\
\hline \multirow[t]{3}{*}{ Ligustrum vulgare $(C p, Q p p)$} & B1 & - & - & - & - & - & + & - & + & - & - & - & - & - & - & - & - & - & - & - & - & + & I & 10 \\
\hline & B2 & - & - & - & - & + & + & + & - & - & + & - & - & - & + & - & - & - & - & - & - & + & II & 25 \\
\hline & S & - & - & - & - & + & + & + & + & - & + & - & - & - & + & - & - & - & - & - & - & + & II & 30 \\
\hline \multirow[t]{4}{*}{ Populus tremula (Qr,Qc,Ber) } & A1 & - & - & - & - & - & 1 & - & - & - & - & - & - & - & - & - & - & - & - & - & - & 1 & I & 5 \\
\hline & B1 & - & - & - & + & - & - & - & - & - & - & - & - & - & - & - & - & - & + & - & + & + & I & 15 \\
\hline & B2 & - & - & - & - & - & - & - & - & - & - & - & + & - & - & - & - & - & - & - & - & + & 1 & 5 \\
\hline & S & - & - & - & + & - & 1 & - & - & - & - & - & + & - & - & - & - & - & + & - & + & +-1 & II & 25 \\
\hline Dactylis polygama (Qpp,Cp) & $\mathrm{C}$ & - & - & - & - & - & - & + & - & - & - & - & - & - & + & - & + & - & - & - & + & + & 1 & 20 \\
\hline Geum urbanum (Epa,Cp,Qpp) & C & - & - & - & - & - & + & - & - & - & - & - & - & + & - & - & - & + & - & + & - & + & I & 20 \\
\hline Fragaria vesca (Qpp,Epa) & $\mathrm{C}$ & - & - & - & - & - & - & - & - & - & - & - & - & - & - & - & - & - & - & + & + & + & I & 10 \\
\hline Lapsana communis (Qpp,GA,Epa) & C & - & - & - & - & - & - & - & - & - & - & - & - & + & - & - & + & - & - & - & - & + & I & 10 \\
\hline \multirow[t]{3}{*}{ Ulmus minor (Ai,Ulm,Qpp) } & B1 & - & - & - & + & - & - & - & - & - & - & - & - & - & - & - & - & - & - & - & - & + & I & 5 \\
\hline & B2 & - & - & - & + & + & - & - & - & - & - & - & - & - & - & - & - & - & - & - & - & + & I & 10 \\
\hline & S & - & - & - & + & + & - & - & - & - & - & - & - & - & - & - & - & - & - & - & - & + & I & 10 \\
\hline Acer campestre (Qpp) & B2 & - & - & - & - & - & - & - & - & - & - & - & - & - & - & + & - & - & - & - & - & + & I & 5 \\
\hline Carex divulsa & C & - & - & - & - & - & + & - & - & - & - & - & - & - & - & - & - & - & - & - & - & + & I & 5 \\
\hline Convallaria majalis (Qpp) & C & - & - & - & - & - & - & - & - & - & - & + & - & - & - & - & - & - & - & - & - & + & 1 & 5 \\
\hline \multicolumn{25}{|l|}{ 1.3.1. Fagetalia sylvaticae } \\
\hline Moehringia trinervia & C & - & - & + & - & - & + & + & - & + & - & - & - & - & + & + & - & + & + & + & + & + & III & 50 \\
\hline Circaea lutetiana (Ai) & C & - & - & - & - & - & + & - & - & - & - & - & - & - & + & - & - & - & - & + & + & + & I & 20 \\
\hline Galeopsis speciosa (Epn,Ai) & $\mathrm{C}$ & - & - & - & - & - & + & + & - & - & - & - & - & + & + & - & - & - & - & - & - & + & I & 20 \\
\hline Athyrium filix-femina ( $Q r, V P)$ & $\mathrm{C}$ & - & - & - & - & - & + & + & + & - & - & - & - & - & - & - & - & - & - & - & - & + & I & 15 \\
\hline Dryopteris & C & - & - & - & - & + & + & - & + & - & - & - & - & - & - & - & - & - & - & - & - & + & 1 & 15 \\
\hline Cerasus avium (Cp) & B1 & - & - & - & - & - & - & - & - & - & - & - & - & - & - & - & - & - & - & - & + & + & 1 & 5 \\
\hline Listera ovata (Ate,Ai) & C & - & - & - & - & - & - & + & - & - & - & - & - & - & - & - & - & - & - & - & - & + & 1 & 5 \\
\hline \multicolumn{25}{|l|}{ 1.3.1.1. Alnion incanae } \\
\hline \multirow[t]{3}{*}{ Frangula alnus (Ate, $, \mathrm{Qr}, \mathrm{PQ})$} & B1 & - & + & 2 & + & + & - & + & + & + & + & + & 1 & 2 & 1 & 1 & 2 & - & 1 & + & 1 & +-2 & v & 85 \\
\hline & B2 & + & + & + & + & + & + & + & + & + & - & + & + & + & + & + & + & + & + & + & + & + & V & 95 \\
\hline & s & + & + & 2 & + & + & + & + & + & + & + & + & 1 & 2 & 1 & 1 & 2 & + & 1 & + & 1 & +-2 & v & 100 \\
\hline \multirow[t]{3}{*}{ Viburnum opulus (Ate) } & B1 & - & - & + & - & - & 1 & + & + & - & + & - & - & - & + & - & - & + & - & - & + & +-1 & II & 40 \\
\hline & B2 & - & - & + & - & + & + & + & + & + & + & - & + & - & + & + & - & + & + & + & + & + & IV & 70 \\
\hline & s & - & - & + & - & + & 1 & + & + & + & + & - & + & - & + & + & - & + & + & + & + & +-1 & IV & 70 \\
\hline \multirow[t]{3}{*}{ Ribes rubrum } & B1 & - & - & + & - & - & + & + & - & - & - & - & - & - & - & - & - & - & - & - & + & + & I & 20 \\
\hline & B2 & - & - & + & - & - & - & - & - & - & + & - & - & - & + & + & + & + & + & - & + & + & II & 40 \\
\hline & $\mathrm{s}$ & - & - & + & - & - & + & + & - & - & + & - & - & - & + & + & + & + & + & - & + & + & III & 50 \\
\hline Festuca gigantea (Cal,Epa) & C & - & - & - & - & + & + & + & - & + & - & - & + & + & - & + & + & + & - & - & - & + & III & 45 \\
\hline \multirow[t]{4}{*}{ Populus alba (Sal,AQ) } & A1 & - & - & - & - & + & + & - & + & - & - & - & - & - & - & - & - & - & - & - & - & + & 1 & 15 \\
\hline & B1 & - & - & - & - & - & - & - & - & - & - & - & - & - & + & - & - & - & - & - & - & + & 1 & 5 \\
\hline & B2 & - & + & + & - & - & + & - & + & - & - & - & - & - & - & - & - & - & - & - & - & + & 1 & 20 \\
\hline & $\mathrm{S}$ & - & + & + & - & + & + & - & + & - & - & - & - & - & + & - & - & - & - & - & - & + & II & 30 \\
\hline Elymus caninus (Pna,Qpp) & C & - & + & - & - & - & + & - & - & - & - & - & - & + & + & - & - & - & - & - & - & + & 1 & 20 \\
\hline Padus avium & B1 & - & - & - & - & - & - & - & - & - & - & - & - & - & - & + & - & + & - & + & - & + & 1 & 15 \\
\hline & B2 & - & - & - & - & - & - & - & - & - & - & - & - & - & - & + & - & - & - & + & - & + & 1 & 10 \\
\hline & S & - & - & - & - & - & - & - & - & - & - & - & - & - & - & + & - & + & - & + & - & + & 1 & 15 \\
\hline Malus sylvestris (Qpp) & B1 & - & - & - & - & - & - & - & - & - & - & - & - & - & - & - & - & - & - & - & + & + & I & 5 \\
\hline 1.4. Quercetea pubescenti & & & & & & & & & & & & & & & & & & & & & & & & \\
\hline Rosa canina agg. (Pru,Prf) & B1 & - & - & - & - & - & + & - & - & - & + & - & - & - & - & - & + & + & 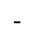 & - & + & + & $\|$ & 25 \\
\hline & B2 & - & - & - & - & - & + & - & + & + & - & - & - & - & + & - & - & + & + & + & - & + & II & 35 \\
\hline & $\mathrm{s}$ & - & - & - & - & - & + & - & + & + & + & - & - & - & + & - & + & + & + & + & + & + & IIII & 50 \\
\hline
\end{tabular}




\begin{tabular}{|c|c|c|c|c|c|c|c|c|c|c|c|c|c|c|c|c|c|c|c|c|c|c|c|c|}
\hline \multicolumn{2}{|l|}{ 1/3. táblázat } & 12 & 23 & 34 & & & & & & & $\overline{101}$ & & & 13 & 14 & & $\overline{161}$ & & 18 & & & A-D & K & $\%$ \\
\hline \multirow[t]{3}{*}{ Prunus spinosa (Pru,Prf) } & B1 & - & & - & 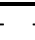 & - & - & - & - & - & + & - & 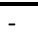 & - & - & - & - & - & - & & + & + & 1 & 10 \\
\hline & B2 & - & & $-\quad-$ & - & - & - & - & - & - & & - & - & - & + & - & - & - & - & - & & + & 1 & 5 \\
\hline & $\mathrm{s}$ & - & - - & - - & - & - & - & - & - & - & + & - & - & - & + & - & - & - & - & & $T_{1}$ & + & 1 & 15 \\
\hline Euonymus verrucosus (Pru) & B1 & - & - - & - - & - & - & - & - & - & - & - & - & - & - & - & + & - & - & - & - & - & + & 1 & 5 \\
\hline Pyrus pyraster (Cp) & B2 & - & - & $-\quad-$ & - & + & - & - & - & - & - & - & - & - & - & - & - & - & - & & - & + & 1 & 5 \\
\hline Quercus cerris ( $Q r, P Q)$ & B2 & - & - & $-\quad-$ & - & - & - & - & - & - & - & - & - & - & + & - & - & - & - & - & . & + & I & 5 \\
\hline \multicolumn{25}{|l|}{ 1.4.1. Quercetalia cerridis } \\
\hline \multicolumn{25}{|l|}{ 1.4.1.1. Aceri tatarici-Quercion } \\
\hline Acer tataricum (Qpp) & B2 & - & $-\quad-$ & $-\quad-$ & - & - & - & - & - & - & - & - & - & - & - & - & - & - & - & & + & + & 1 & 5 \\
\hline \multicolumn{25}{|l|}{ 2. Lemno-Potamea } \\
\hline Lemna minor (HyL,Le) & C & ++ & +1 & $1+$ & + & - & - & + & 2 & 2 & + & - & + & - & - & - & - & + & + & + & - & +-2 & III & 60 \\
\hline Lemna tri & C & -+ & ++ & +- & - & - & - & - & + & - & + & - & + & - & - & - & - & 1 & 1 & & + & +-1 & III & 45 \\
\hline \multicolumn{25}{|l|}{ 2.1. Potametea } \\
\hline \multicolumn{25}{|l|}{ 2.1.1. Potametalia } \\
\hline Batrachium trichophyllum & C & . & ++ & + & - & - & - & + & + & - & + & + & - & - & - & - & - & - & - & - & - & + & ॥ & 30 \\
\hline \multicolumn{25}{|l|}{ 3. Cypero-Phragmitea } \\
\hline \multicolumn{25}{|l|}{ 3.1. Phragmitetea } \\
\hline Carex acutiformis (Mag, Cgr, Mo & C & 13 & 33 & 31 & 12 & 23 & 3 & 2 & + & 1 & 1 & 3 & 4 & 4 & 3 & 3 & 2 & 1 & 2 & & 3 & +-4 & V & 100 \\
\hline Galiun & C & + & $1+$ & ++ & +1 & 1 & 1 & 1 & + & 1 & 1 & 1 & + & + & + & + & 1 & + & + & & + & +-1 & v & 100 \\
\hline Solanum dulcamara (Cal,Bia,Spu) & B1 & - & +- & -+ & ++ & + & - & - & - & + & - & - & + & - & - & - & - & - & - & - & - & + & II & 25 \\
\hline & C & 1 & ++ & ++ & + & + & 1 & + & 1 & + & + & + & 1 & + & + & + & + & 1 & + & & + & +-1 & V & 100 \\
\hline & S & 1 & ++ & ++ & ++ & + & 1 & + & 1 & + & + & + & 1 & + & + & + & + & 1 & + & & + & +-1 & v & 100 \\
\hline Iris pseudacorus (Sal,Ate,Ai) & C & + & 11 & 1. & -1 & 1 & 1 & 1 & 1 & 2 & 2 & + & + & 1 & + & 1 & + & + & + & + & + & +-2 & $v$ & 95 \\
\hline Mag,Cgr,MoJ,Sal,Ate) & C & +2 & 22 & $2+$ & +1 & 1 & - & - & 1 & - & + & 2 & 2 & 1 & 1 & 1 & 1 & + & 1 & + & 2 & +-2 & $\mathrm{~V}$ & 85 \\
\hline Stachys & C & + & $1+$ & +1 & 1 & + & + & + & 1 & - & 1 & + & + & 1 & + & + & + & - & + & - & + & +-1 & v & 85 \\
\hline Lycopi & C & + & ++ & ++ & + & + & + & - & 1 & - & + & + & + & + & + & + & - & + & - & + & + & +-1 & IV & 80 \\
\hline Eupat & $c$ & - & ++ & ++ & + & + & + & 1 & + & 1 & 1 & + & - & + & + & + & - & - & - & + & + & +-1 & IV & 75 \\
\hline Roripp & C & 1 & +1 & $1+$ & + & + & - & + & - & + & 1 & + & + & - & - & + & + & + & + & + & - & +-1 & IV & 75 \\
\hline Poa $p$ & C & + & - & -+ & + & + & - & - & 1 & - & + & - & + & + & + & - & + & + & + & & + & +-1 & IV & 65 \\
\hline Scute & C & + & ++ & + & + & + & - & + & - & + & + & + & + & - & + & - & - & - & + & + & - & + & IV & 65 \\
\hline Oenar & c & + & ++ & ++ & + & - & - & + & 1 & 1 & + & - & + & - & - & - & - & 1 & 1 & + & - & +-1 & III & 60 \\
\hline Cirsi & C & + & -+ & + & - & - & - & + & - & - & - & + & + & - & + & - & - & + & - & + & + & + & III & 45 \\
\hline Phra & C & + & +1 & 12 & 2 & - & - & + & - & - & - & - & - & + & + & - & + & + & - & - & 1 & +-2 & III & 45 \\
\hline Glyce & C & - & - & -+ & + & + & - & + & - & + & 1 & + & + & - & - & - & - & - & - & + & - & +-1 & II & 40 \\
\hline Sparg & C & + & ++ & + & + & - & - & - & + & + & + & - & - & - & - & - & - & - & - & + & - & + & II & 40 \\
\hline Alism & C & + & - & - & - & - & - & - & - & + & - & + & + & - & - & - & - & + & + & + & - & + & II & 35 \\
\hline Myos & C & 1 & - & - & - & - & - & + & 1 & + & - & - & - & - & - & - & - & - & - & - & - & +-1 & 1 & 20 \\
\hline Alism & $c$ & - & + & - & - & + & - & - & - & - & - & - & - & + & - & - & - & - & - & - & - & + & 1 & 15 \\
\hline Epilot & C & - & - & - & - & - & + & - & + & - & - & + & - & - & - & - & - & - & - & - & - & + & 1 & 15 \\
\hline Нype & $c$ & - & - & - & - & - & + & - & - & - & - & - & + & + & - & - & - & - & - & - & - & + & 1 & 15 \\
\hline Sch & C & - & - & -+ & + & - & - & - & - & + & + & - & - & - & - & - & - & - & - & - & & + & 1 & 15 \\
\hline Typh & $c$ & - & + & - & + & - & - & - & - & + & - & - & - & - & - & - & - & - & - & - & - & + & 1 & 15 \\
\hline Glyce & C & - & - & - & - & - & - & - & - & - & - & - & + & - & - & - & - & + & - & - & - & + & 1 & 10 \\
\hline Phala & C & 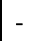 & - & - & - & - & + & - & 1 & - & - & - & - & - & - & - & - & - & - & - & - & +-1 & 1 & 10 \\
\hline Epilot & $c$ & - & - & - & - & - & - & - & - & - & - & - & + & - & - & - & - & - & - & - & & + & 1 & 5 \\
\hline Euphorbia $p$ & C & 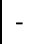 & - & - & - & + & - & - & - & - & - & - & - & - & - & - & - & - & - & & & + & 1 & 5 \\
\hline & & & & & & & & & & & & & & & & & & & & & & & & \\
\hline & & & & & & & & & & & & & & & & & & & & & & & & \\
\hline Urtica kioviensis (Ate) & C & 2 & 11 & 1 & $\boldsymbol{T}$ & & & + & + & + & + & + & + & + & - & - & + & $T$ & + & & + & +-2 & $\mathrm{v}$ & 90 \\
\hline 3.1.2. & & & & & & & & & & & & & & & & & & & & & & & & \\
\hline & & & & & & & & & & & & & & & & & & & & & & & & \\
\hline & C & + & - & - & + & - & - & + & 1 & + & - & + & - & - & + & - & - & + & + & & + & +-1 & III & 55 \\
\hline Vero & c & - & ++ & + & - & - & - & + & - & + & 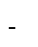 & - & + & - & - & - & - & - & - & - & & + & ॥ & 25 \\
\hline Scrophularia umbrosa (Ai) & C & - & - - & - & - & - & - & - & - & - & - & + & - & - & + & - & - & - & - & + & & + & 1 & 15 \\
\hline
\end{tabular}




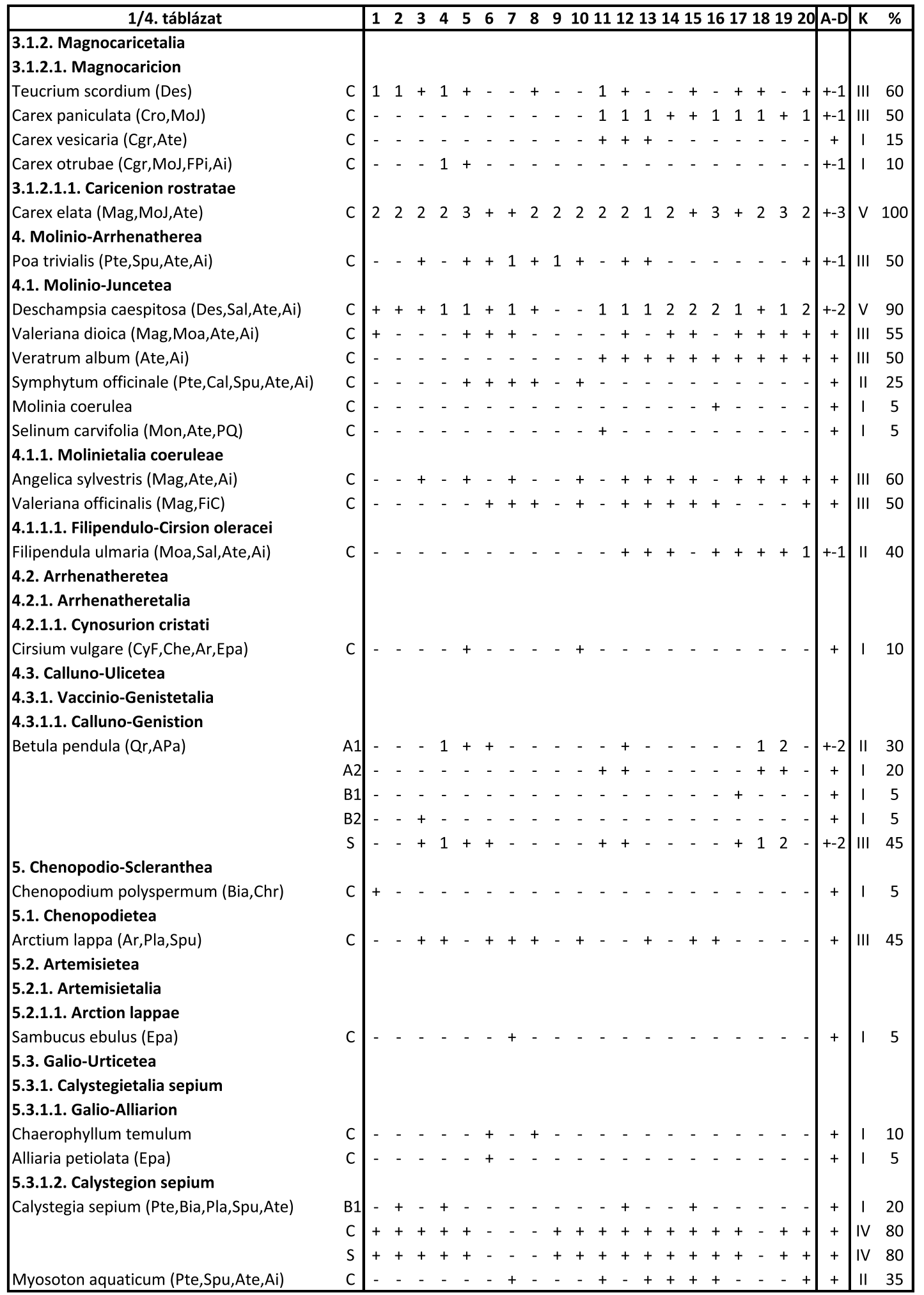




\begin{tabular}{|c|c|c|c|c|c|c|c|c|c|c|c|c|c|c|c|c|c|c|c|c|c|c|c|c|}
\hline \multicolumn{2}{|l|}{ 1/5. táblázat } & 1 & \multirow[t]{2}{*}{2} & 3 & \multirow[t]{2}{*}{4} & \multirow[t]{2}{*}{5} & 6 & 7 & 8 & 9 & & & & & & & & & 10 & & & $A-D$ & $\mathbf{K}$ & $\%$ \\
\hline 5.4. Bidentetea & & & & & & & & & & & & & & & & & & & & & & & & \\
\hline 1. Bidentetalia & & & & & & & & & & & & & & & & & & & & & & & & \\
\hline Bidens tripartita (Pte, Nc,Sea,Sal) & $\mathrm{C}$ & + & - & + & + & + & - & + & + & + & 1 & - & + & + & + & + & - & - & + & - & + & +-1 & IV & 70 \\
\hline Alopecurus aequalis & $\mathrm{C}$ & - & - & - & + & - & - & + & - & + & + & - & + & - & - & + & + & + & + & + & - & + & III & 50 \\
\hline Persicaria hydropiper (Nc,Bin,Spu,Ate,Ai) & $\mathrm{C}$ & - & - & - & - & - & - & - & - & - & - & - & - & + & + & 1 & + & - & + & - & + & +-1 & II & 30 \\
\hline Persicaria dubia (Alo,Bin,Spu,Ai) & $\mathrm{C}$ & - & - & - & - & - & - & - & - & - & - & - & - & - & + & + & + & - & - & - & - & + & I & 15 \\
\hline Persicaria minor (Des,Bin,Spu,Ate,Ai) & $\mathrm{C}$ & - & - & - & - & - & - & - & - & + & - & - & - & - & - & - & - & - & - & - & - & + & 1 & 5 \\
\hline 5.5. Epilobietea angustifolii & & & & & & & & & & & & & & & & & & & & & & & & \\
\hline 5.5.1. Epilobietalia & & & & & & & & & & & & & & & & & & & & & & & & \\
\hline Epilobium obscurum (NG,CM,Ccn) & $\mathrm{C}$ & - & - & - & - & - & + & + & - & - & - & - & - & - & - & - & - & - & - & - & - & + & 1 & 10 \\
\hline 6. Indifferens & & & & & & & & & & & & & & & & & & & & & & & & \\
\hline Lysimachia vulgaris (Ai,Pte,SCn,MoJ,Sal) & C & + & 1 & + & + & 1 & 1 & + & + & 1 & 1 & + & + & + & + & 1 & 1 & + & 1 & + & + & +-1 & V & 100 \\
\hline Rubus caesius (Spu) & B2 & - & + & + & + & + & + & 1 & + & + & + & + & + & 2 & 2 & 2 & 1 & + & + & 1 & + & +-2 & V & 95 \\
\hline Lythrum salicaria (Pte,MoJ,Bia,Spu,Ate) & $\mathrm{C}$ & + & + & + & + & 1 & - & + & 1 & + & + & + & + & + & + & + & + & - & + & + & + & +-1 & $\mathrm{~V}$ & 90 \\
\hline Ranunculus repens (Pte,MoA,ChS,Spu,Ate) & $\mathrm{C}$ & - & - & + & + & 1 & 1 & + & + & + & + & + & + & + & + & + & + & + & + & + & + & +-1 & V & 90 \\
\hline Equisetum arvense (MoA,Sea,Sal,Ate,Ai) & $\mathrm{C}$ & - & + & + & + & + & + & 1 & + & + & + & - & + & + & + & + & + & - & - & + & + & +-1 & IV & 80 \\
\hline Mentha aquatica (Pte,Moa,Spu,Ate,Ai) & $\mathrm{C}$ & 2 & + & + & 1 & + & + & + & 1 & + & + & - & - & - & + & + & - & - & - & - & - & +-2 & III & 60 \\
\hline Agrostis stolonifera (Pte,MoJ,FPe,Bia,Pla) & $\mathrm{C}$ & + & - & - & + & + & - & - & - & - & - & - & + & - & + & + & + & + & + & + & - & + & III & 50 \\
\hline Lysimachia nummularia (Pte,MoJ,Bia) & $\mathrm{C}$ & - & - & - & + & + & + & - & + & + & + & - & - & - & - & + & - & + & - & - & + & + & III & 45 \\
\hline Calamagrostis epigeios (MoJ,Fvg,Epa) & $\mathrm{C}$ & + & + & - & - & - & - & - & - & - & - & + & - & - & + & - & + & + & + & - & + & + & II & 40 \\
\hline Urtica dioica (Ar,GA,Epa,Spu) & $\mathrm{C}$ & - & - & + & - & - & + & + & - & - & + & + & - & + & - & + & + & - & - & - & - & + & II & 40 \\
\hline Caltha palustris (Mag,MoJ,Spu,Ate,Ai) & $\mathrm{C}$ & - & - & - & - & + & + & + & - & - & - & - & - & - & + & + & - & + & - & - & + & + & II & 35 \\
\hline Sambucus nigra (Epa,US,QFt) & B1 & - & - & + & - & - & - & + & - & + & + & - & + & - & - & - & - & - & - & - & - & + & II & 25 \\
\hline & B2 & - & - & - & - & - & - & - & + & + & - & - & - & + & - & - & - & - & - & - & - & + & 1 & 15 \\
\hline & $\mathrm{S}$ & - & - & + & - & - & - & + & + & + & + & - & + & + & - & - & - & - & - & - & - & + & II & 35 \\
\hline Ranunculus sceleratus (Pte,Nc,Bia,Bin,Sal) & $\mathrm{C}$ & - & + & + & - & + & - & + & - & + & - & - & - & + & - & - & - & - & - & - & - & + & II & 30 \\
\hline Persicaria amphibia (Pte,Moa,Bia,Spu,Ate) & $\mathrm{C}$ & + & + & - & 1 & - & - & - & - & - & - & + & + & - & - & - & - & - & - & - & - & +-1 & II & 25 \\
\hline Carex hirta (Pte,MoA,Pla) & $\mathrm{C}$ & - & - & - & + & - & + & + & - & - & - & - & - & - & - & + & - & - & - & - & - & + & 1 & 20 \\
\hline Chelidonium majus (Che,Ar,GA,Epa) & C & - & - & - & - & - & - & - & - & + & - & - & - & + & - & - & + & - & - & - & + & + & 1 & 20 \\
\hline Glechoma hederacea (MoA,QFt,Sal,Ai) & $\mathrm{C}$ & - & - & - & - & - & - & + & + & + & + & - & - & - & - & - & - & - & - & - & - & + & 1 & 20 \\
\hline Galium aparine (Sea,Epa,QFt) & $\mathrm{C}$ & - & - & - & - & - & + & + & - & - & - & - & - & - & - & - & - & - & - & - & - & + & 1 & 10 \\
\hline Potentilla reptans (Mag,MoA,FPi,Bia,Pla) & $\mathrm{C}$ & - & - & - & + & - & - & + & - & - & - & - & - & - & - & - & - & - & - & - & - & + & 1 & 10 \\
\hline Stellaria media (ChS,QFt,Spu) & $\mathrm{C}$ & - & - & - & - & - & - & - & + & - & + & - & - & - & - & - & - & - & - & - & - & + & 1 & 10 \\
\hline Cirsium arvense (Nc,ChS,Epa) & $\mathrm{C}$ & - & - & - & - & - & - & - & + & - & - & - & - & - & - & - & - & - & - & - & - & + & 1 & 5 \\
\hline Juncus articulatus (Pte,Nc,MoJ,Bia,Pla) & $\mathrm{C}$ & - & - & - & - & - & - & - & - & - & + & - & - & - & - & - & - & - & - & - & - & + & 1 & 5 \\
\hline Persicaria lapathifolia (Pte, Nc,ChS,Bia,Str) & $\mathrm{C}$ & - & - & - & - & - & - & + & - & - & - & - & - & - & - & - & - & - & - & - & - & + & 1 & 5 \\
\hline Persicaria maculosa (Pte, $\mathrm{Nc}, \mathrm{ChS}$ ) & $\mathrm{C}$ & - & - & - & - & - & - & - & - & - & + & - & - & - & - & - & - & - & - & - & - & + & 1 & 5 \\
\hline Plantago major (Pla) & $\mathrm{C}$ & - & - & - & - & - & - & - & + & - & - & - & - & - & - & - & - & - & - & - & - & + & 1 & 5 \\
\hline 7. A & & & & & & & & & & & & & & & & & & & & & & & & \\
\hline Solidago & C & - & - & + & - & + & - & - & - & + & - & + & + & + & + & + & + & + & + & + & + & + & IV & 65 \\
\hline Fraxinus pennsylvanica & A1 & - & - & - & - & - & - & - & 2 & - & + & - & - & - & - & - & - & - & - & - & - & +-2 & 1 & 10 \\
\hline & A2 & - & - & - & + & 2 & 1 & + & 2 & - & 1 & - & - & - & - & - & - & - & - & - & - & +-2 & II & 30 \\
\hline & B1 & + & - & + & + & 2 & 1 & - & 3 & + & + & - & - & - & - & + & - & - & - & - & - & +-3 & III & 45 \\
\hline & B2 & + & - & - & - & - & + & + & 1 & - & + & - & - & - & - & - & - & - & - & - & - & +-1 & II & 25 \\
\hline & $\mathrm{S}$ & + & - & + & + & 3 & 2 & + & 4 & + & 1 & - & - & - & - & + & - & - & - & - & - & +-4 & III & 50 \\
\hline Acer negundo & A2 & - & - & - & - & - & 1 & - & - & - & - & - & - & - & - & - & - & - & - & - & - & 1 & 1 & 5 \\
\hline & B1 & - & - & - & - & - & 2 & - & - & - & - & - & - & - & - & - & - & - & - & - & - & 2 & I & 5 \\
\hline & B2 & - & - & + & - & - & - & - & - & - & - & - & - & + & - & - & - & - & - & - & - & + & 1 & 10 \\
\hline & $\mathrm{S}$ & - & - & + & - & - & 2 & - & - & - & - & - & - & + & - & - & - & - & - & - & - & +-2 & 1 & 15 \\
\hline Gleditsia triacanthos & B2 & - & - & - & - & - & - & - & + & + & - & - & - & - & - & - & - & + & - & - & - & + & 1 & 15 \\
\hline Asclepias syriaca & $\mathrm{C}$ & - & - & - & - & - & - & - & - & - & - & - & - & - & - & + & - & - & - & - & - & + & 1 & 5 \\
\hline Aster salignus & $\mathrm{C}$ & - & - & - & - & - & - & - & - & - & - & - & - & - & + & - & - & - & - & - & - & + & 1 & 5 \\
\hline Celtis occidentalis & B2 & - & - & - & - & - & - & - & - & - & - & - & - & - & - & - & - & - & + & - & - & + & 1 & 5 \\
\hline Erigeron canadensis & $\mathrm{C}$ & - & - & - & - & - & - & - & - & - & + & - & - & - & - & - & - & - & - & - & - & + & 1 & 5 \\
\hline Robinia pseudo-acacia & B2 & - & - & - & - & - & - & - & - & - & - & - & - & - & - & - & + & - & - & - & - & + & 1 & 5 \\
\hline Vitis riparia & B1 & - & - & - & - & - & - & - & - & - & - & - & + & - & - & - & - & - & - & - & - & + & 1 & 5 \\
\hline
\end{tabular}




\begin{tabular}{|c|c|}
\hline & 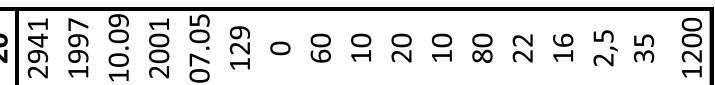 \\
\hline 9 & 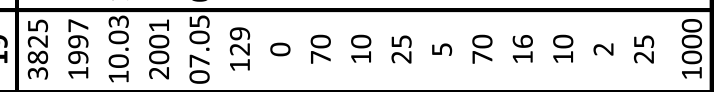 \\
\hline & 雨 \\
\hline & $\mid \begin{array}{l}\prod_{\infty} \\
\infty \\
m\end{array}$ \\
\hline & 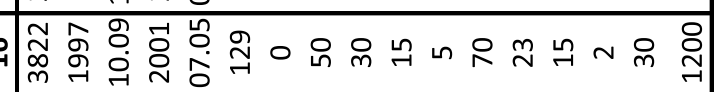 \\
\hline & 吾 \\
\hline & 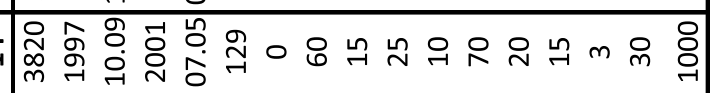 \\
\hline & 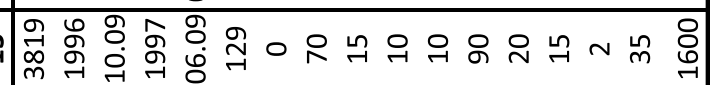 \\
\hline & 竞 \\
\hline & 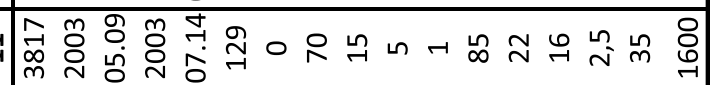 \\
\hline & 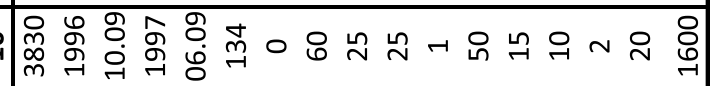 \\
\hline & 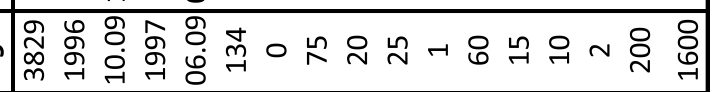 \\
\hline & 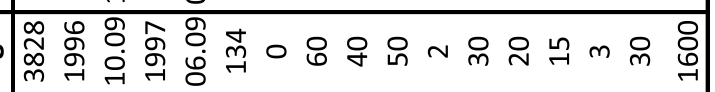 \\
\hline & 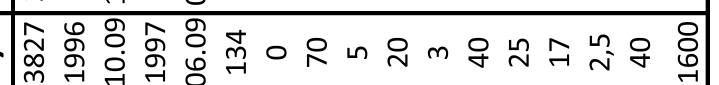 \\
\hline & 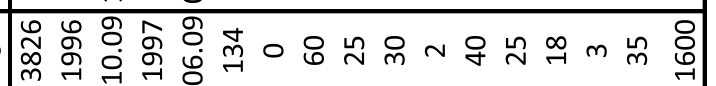 \\
\hline in & 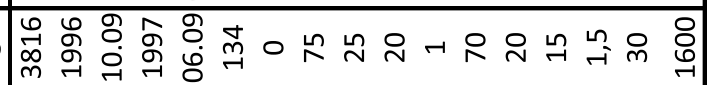 \\
\hline+ & 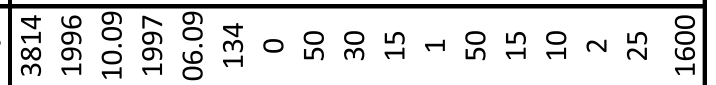 \\
\hline$m$ & 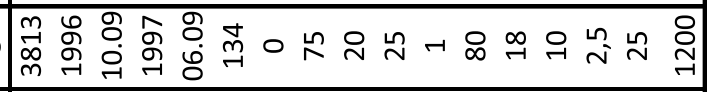 \\
\hline$N$ & 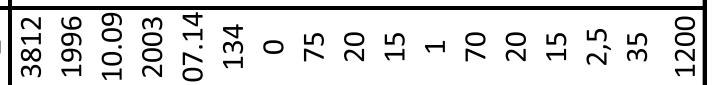 \\
\hline 4 & 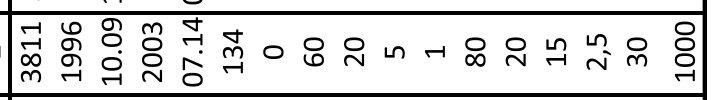 \\
\hline \multicolumn{2}{|r|}{ 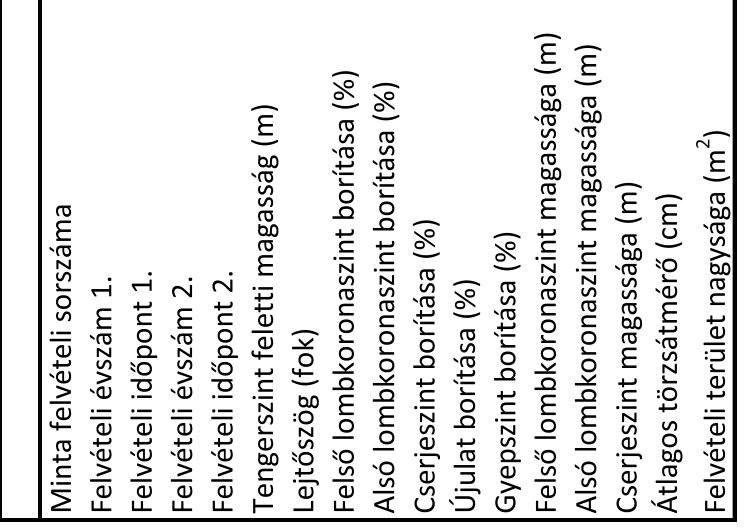 } \\
\hline
\end{tabular}


(CARICI ELONGATAE-ALNETUM GLUTINOSAE W. KOCH 1926)

3. táblázat. Karakterfajok aránya

\begin{tabular}{|c|c|c|c|c|c|c|}
\hline \multirow{2}{*}{ 3/1. táblázat } & \multicolumn{3}{|c|}{ Csoportrészesedés } & \multicolumn{3}{|c|}{ Csoporttömeg } \\
\hline & Th & Szk & BS & Th & Szk & BS \\
\hline Querco-Fagea & 0,0 & 0,0 & 0,0 & 0,0 & 0,0 & 0,0 \\
\hline Salicetea purpureae & 0,0 & 0,0 & 0,0 & 0,0 & 0,0 & 0,0 \\
\hline Salicetalia purpureae & 5,8 & 5,7 & 6,5 & 2,1 & 3,5 & 3,2 \\
\hline Salicion albae & 3,3 & 4,8 & 3,2 & 3,7 & 4,0 & 2,8 \\
\hline Populenion nigro-albae & 0,1 & 0,1 & 0,1 & 0,0 & 0,0 & 0,0 \\
\hline Salicion albae s.l. & 3,4 & 4,9 & 3,3 & 3,7 & 4,0 & 2,8 \\
\hline Salicetalia purpureae s.l. & 9,2 & 10,6 & 9,8 & 5,8 & 7,5 & 6,0 \\
\hline Salicetea purpureae s.I. & 9,2 & 10,6 & 9,8 & 5,8 & 7,5 & 6,0 \\
\hline Alnetea glutinosae & 0,0 & 0,0 & 0,0 & 0,0 & 0,0 & 0,0 \\
\hline Alnetalia glutinosae & 11,4 & 10,0 & 12,2 & 22,1 & 20,6 & 23,2 \\
\hline Alnion glutinosae & 1,4 & 2,3 & 2,6 & 1,5 & 4,5 & 2,3 \\
\hline Alnetalia glutinosae s.l. & 12,8 & 12,3 & 14,8 & 23,6 & 25,1 & 25,5 \\
\hline Alnetea glutinosae s.l. & 12,8 & 12,3 & 14,8 & 23,6 & 25,1 & 25,5 \\
\hline Querco-Fagetea & 6,1 & 6,1 & 3,2 & 1,9 & 2,2 & 0,8 \\
\hline Fagetalia sylvaticae & 1,9 & 2,8 & 5,9 & 0,6 & 0,3 & 1,3 \\
\hline Alnion incanae & 8,5 & 9,0 & 8,8 & 16,6 & 17,0 & 17,8 \\
\hline Alnenion glutinosae-incanae & 0,9 & 0,9 & 1,4 & 14,0 & 12,3 & 14,2 \\
\hline Ulmenion & 0,1 & 0,5 & 0,5 & 0,0 & 0,3 & 0,1 \\
\hline Alnion incanae s.l. & 9,5 & 10,4 & 10,7 & 30,6 & 29,6 & 32,1 \\
\hline Fagion sylvaticae & 0,0 & 0,0 & 0,0 & 0,0 & 0,0 & 0,0 \\
\hline Eu-Fagenion & 0,0 & 0,0 & 0,1 & 0,0 & 0,0 & 0,0 \\
\hline Carpinenion betuli & 0,7 & 0,4 & 0,4 & 0,1 & 0,0 & 0,0 \\
\hline Tilio-Acerenion & 0,4 & 0,7 & 0,2 & 0,1 & 0,5 & 0,0 \\
\hline Fagion sylvaticae s.l. & 1,1 & 1,1 & 0,7 & 0,2 & 0,5 & 0,0 \\
\hline Fagetalia sylvaticae s.l. & 12,5 & 14,3 & 17,3 & 31,4 & 30,4 & 33,4 \\
\hline Quercetalia roboris & 1,3 & 0,5 & 1,7 & 1,0 & 0,2 & 0,8 \\
\hline Querco-Fagetea s.I. & 19,9 & 20,9 & 22,2 & 34,3 & 32,8 & 35,0 \\
\hline Quercetea pubescentis-petraeae & 4,9 & 5,2 & 2,0 & 1,7 & 2,1 & 0,6 \\
\hline Quercetalia cerridis & 0,1 & 0,0 & 0,0 & 0,0 & 0,0 & 0,0 \\
\hline Aceri tatarici-Quercion & 0,2 & 0,3 & 0,0 & 0,0 & 0,3 & 0,0 \\
\hline Quercetalia cerridis s.I. & 0,3 & 0,3 & 0,0 & 0,0 & 0,3 & 0,0 \\
\hline Prunetalia spinosae & 0,7 & 0,3 & 0,1 & 0,1 & 0,0 & 0,0 \\
\hline Berberidion & 0,1 & 0,0 & 0,0 & 0,0 & 0,0 & 0,0 \\
\hline Prunion fruticosae & 0,4 & 0,1 & 0,0 & 0,1 & 0,0 & 0,0 \\
\hline Prunetalia spinosae s.l. & 1,2 & 0,4 & 0,1 & 0,2 & 0,0 & 0,0 \\
\hline Quercetea pubescentis-petraeae s.I. & 6,4 & 5,9 & 2,1 & 1,9 & 2,4 & 0,6 \\
\hline Querco-Fagea s.I. & 48,3 & 49,7 & 48,9 & 65,6 & 67,8 & 67,1 \\
\hline
\end{tabular}




\begin{tabular}{|c|c|c|c|c|c|c|}
\hline \multirow{2}{*}{ 3/2. táblázat } & \multicolumn{3}{|c|}{ Csoportrészesedés } & \multicolumn{3}{|c|}{ Csoporttömeg } \\
\hline & Th & Szk & BS & Th & Szk & BS \\
\hline Abieti-Piceea & 0,3 & 0,0 & 0,1 & 0,2 & 0,0 & 0,0 \\
\hline Vaccinio-Piceetea & 0,4 & 0,1 & 1,2 & 0,4 & 0,0 & 0,7 \\
\hline Pino-Quercetalia & 0,0 & 0,0 & 0,0 & 0,0 & 0,0 & 0,0 \\
\hline Pino-Quercion & 0,7 & 0,7 & 0,4 & 0,4 & 0,2 & 0,1 \\
\hline Pino-Quercetalia s.I. & 1,1 & 0,8 & 1,6 & 0,8 & 0,2 & 0,8 \\
\hline Vaccinio-Piceetea s.I. & 1,1 & 0,8 & 1,6 & 0,8 & 0,2 & 0,8 \\
\hline Abieti-Piceea s.l. & 1,4 & 0,8 & 1,7 & 1,0 & 0,2 & 0,8 \\
\hline Lemno-Potamea & 0,8 & 0,9 & 0,9 & 0,4 & 0,1 & 0,4 \\
\hline Hydrochari-Lemnetea & 0,0 & 0,0 & 0,0 & 0,0 & 0,0 & 0,0 \\
\hline Hydrocharietalia & 0,6 & 0,6 & 0,7 & 0,4 & 0,1 & 0,4 \\
\hline Lemnion minoris & 0,6 & 0,8 & 0,6 & 0,4 & 0,1 & 0,4 \\
\hline Hydrocharition & 0,0 & 0,3 & 0,1 & 0,0 & 0,0 & 0,0 \\
\hline Hydrocharietalia s.I. & 1,2 & 1,7 & 1,4 & 0,8 & 0,2 & 0,8 \\
\hline Hydrochari-Lemnetea s.I. & 1,2 & 1,7 & 1,4 & 0,8 & 0,2 & 0,8 \\
\hline Potametea & 0,1 & 0,1 & 0,2 & 0,0 & 0,0 & 0,0 \\
\hline Potametalia & 0,5 & 0,2 & 0,4 & 0,1 & 0,0 & 0,1 \\
\hline Potamion & 0,0 & 0,1 & 0,6 & 0,0 & 0,0 & 0,5 \\
\hline Nymphaeion & 0,0 & 0,1 & 0,2 & 0,0 & 0,0 & 0,0 \\
\hline Potametalia s.I. & 0,5 & 0,4 & 1,2 & 0,1 & 0,0 & 0,6 \\
\hline Potametea s.I. & 0,6 & 0,5 & 1,4 & 0,1 & 0,0 & 0,6 \\
\hline Lemno-Potamea s.l. & 2,6 & 3,1 & 3,7 & 1,3 & 0,3 & 1,8 \\
\hline Cypero-Phragmitea & 0,0 & 0,0 & 0,0 & 0,0 & 0,0 & 0,0 \\
\hline Phragmitetea & 9,1 & 9,4 & 9,5 & 5,3 & 8,6 & 5,1 \\
\hline Phragmitetalia & 0,0 & 0,0 & 0,0 & 0,0 & 0,0 & 0,0 \\
\hline Phragmition & 1,3 & 0,7 & 1,0 & 0,4 & 0,4 & 1,2 \\
\hline Phragmitetalia s.I. & 1,3 & 0,7 & 1,0 & 0,4 & 0,4 & 1,2 \\
\hline Nasturtio-Glycerietalia & 0,0 & 0,0 & 0,0 & 0,0 & 0,0 & 0,0 \\
\hline Glycerio-Sparganion & 1,2 & 0,3 & 1,2 & 0,2 & 0,0 & 0,4 \\
\hline Nasturtio-Glycerietalia s.I. & 1,2 & 0,3 & 1,2 & 0,2 & 0,0 & 0,4 \\
\hline Magnocaricetalia & 0,0 & 0,0 & 0,0 & 0,0 & 0,0 & 0,0 \\
\hline Magnocaricion & 4,1 & 3,4 & 3,6 & 5,9 & 5,1 & 5,6 \\
\hline Caricenion rostratae & 1,2 & 0,9 & 1,4 & 2,2 & 0,6 & 2,6 \\
\hline Caricenion gracilis & 0,7 & 0,8 & 0,6 & 2,5 & 2,4 & 2,1 \\
\hline Magnocaricion s.l. & 6,0 & 5,1 & 5,6 & 10,6 & 8,1 & 10,3 \\
\hline Magnocaricetalia s.l. & 6,0 & 5,1 & 5,6 & 10,6 & 8,1 & 10,3 \\
\hline Phragmitetea s.l. & 17,6 & 15,5 & 17,3 & 16,5 & 17,1 & 17,0 \\
\hline
\end{tabular}




\begin{tabular}{|c|c|c|c|c|c|c|}
\hline \multirow{2}{*}{ 3/3. táblázat } & \multicolumn{3}{|c|}{ Csoportrészesedés } & \multicolumn{3}{|c|}{ Csoporttömeg } \\
\hline & Th & Szk & BS & Th & Szk & BS \\
\hline Isoëto-Nanojuncetea & 0,0 & 0,0 & 0,0 & 0,0 & 0,0 & 0,0 \\
\hline Nanocyperetalia & 0,0 & 0,0 & 0,0 & 0,0 & 0,0 & 0,0 \\
\hline Nanocyperion flavescentis & 0,8 & 0,7 & 0,9 & 0,1 & 0,5 & 1,0 \\
\hline Nanocyperetalia s.I. & 0,8 & 0,7 & 0,9 & 0,1 & 0,5 & 1,0 \\
\hline Isoëto-Nanojuncetea s.I. & 0,8 & 0,7 & 0,9 & 0,1 & 0,5 & 1,0 \\
\hline Montio-Cardaminetea & 0,0 & 0,0 & 0,0 & 0,0 & 0,0 & 0,0 \\
\hline Montio-Cardaminetalia & 0,0 & 0,0 & 0,0 & 0,0 & 0,0 & 0,0 \\
\hline Cardamini-Montion & 0,0 & 0,0 & 0,2 & 0,0 & 0,0 & 0,0 \\
\hline Montio-Cardaminetalia s.I. & 0,0 & 0,0 & 0,2 & 0,0 & 0,0 & 0,0 \\
\hline Montio-Cardaminetea s.l. & 0,0 & 0,0 & 0,2 & 0,0 & 0,0 & 0,0 \\
\hline Cypero-Phragmitea s.I. & 18,4 & 16,2 & 18,4 & 16,6 & 17,6 & 18,0 \\
\hline Oxycocco-Caricea nigrae & 0,0 & 0,0 & 0,0 & 0,0 & 0,0 & 0,0 \\
\hline Scheuchzerio-Caricetea nigrae & 0,0 & 0,0 & 0,0 & 0,0 & 0,0 & 0,0 \\
\hline Scheuchzerio-Caricetalia nigrae & 0,3 & 0,3 & 0,3 & 0,1 & 0,1 & 0,1 \\
\hline Scheuchzerio-Caricetea nigrae s.l. & 0,3 & 0,3 & 0,3 & 0,1 & 0,1 & 0,1 \\
\hline Oxycocco-Caricea nigrae s.l. & 0,3 & 0,3 & 0,3 & 0,1 & 0,1 & 0,1 \\
\hline Molinio-Arrhenatherea & 0,9 & 0,8 & 0,9 & 0,2 & 0,1 & 0,2 \\
\hline Molinio-Juncetea & 4,4 & 4,1 & 3,7 & 5,5 & 4,9 & 4,6 \\
\hline Tofieldietalia & 0,0 & 0,0 & 0,0 & 0,0 & 0,0 & 0,0 \\
\hline Caricion davallianae & 0,0 & 0,1 & 0,0 & 0,0 & 0,0 & 0,0 \\
\hline Tofieldietalia s.I. & 0,0 & 0,1 & 0,0 & 0,0 & 0,0 & 0,0 \\
\hline Molinietalia coeruleae & 1,9 & 1,6 & 1,6 & 0,4 & 0,2 & 0,5 \\
\hline Deschampsion caespitosae & 1,1 & 1,4 & 0,7 & 0,7 & 0,3 & 0,2 \\
\hline Filipendulo-Cirsion oleracei & 0,6 & 0,4 & 0,4 & 0,1 & 0,0 & 0,0 \\
\hline Alopecurion pratensis & 0,1 & 0,1 & 0,1 & 0,0 & 0,0 & 0,2 \\
\hline Molinietalia coeruleae s.I. & 3,7 & 3,5 & 2,8 & 1,2 & 0,5 & 0,9 \\
\hline Molinio-Juncetea s.I. & 8,1 & 7,7 & 6,5 & 6,7 & 5,4 & 5,5 \\
\hline Calluno-Ulicetea & 0,0 & 0,0 & 0,0 & 0,0 & 0,0 & 0,0 \\
\hline Vaccinio-Genistetalia & 0,0 & 0,0 & 0,0 & 0,0 & 0,0 & 0,0 \\
\hline Calluno-Genistion & 0,3 & 0,0 & 0,1 & 0,2 & 0,0 & 0,0 \\
\hline Vaccinio-Genistetalia s.I. & 0,3 & 0,0 & 0,1 & 0,2 & 0,0 & 0,0 \\
\hline Calluno-Ulicetea s.I. & 0,3 & 0,0 & 0,1 & 0,2 & 0,0 & 0,0 \\
\hline Molinio-Arrhenatherea s.I. & 9,3 & 8,5 & 7,5 & 7,1 & 5,5 & 5,7 \\
\hline Puccinellio-Salicornea & 0,0 & 0,0 & 0,0 & 0,0 & 0,0 & 0,0 \\
\hline Festuco-Puccinellietea & 0,3 & 0,4 & 0,2 & 0,1 & 1,4 & 0,0 \\
\hline Festuco-Puccinellietalia & 0,4 & 0,3 & 0,3 & 0,1 & 0,1 & 0,1 \\
\hline Festuco-Puccinellietea s.l. & 0,7 & 0,7 & 0,5 & 0,2 & 1,5 & 0,1 \\
\hline Puccinellio-Salicornea s.I. & 0,7 & 0,7 & 0,5 & 0,2 & 1,5 & 0,1 \\
\hline
\end{tabular}




\begin{tabular}{|c|c|c|c|c|c|c|}
\hline \multirow{2}{*}{ 3/4. táblázat } & \multicolumn{3}{|c|}{ Csoportrészesedés } & \multicolumn{3}{|c|}{ Csoporttömeg } \\
\hline & Th & Szk & BS & Th & Szk & BS \\
\hline Festuco-Bromea & 0,0 & 0,0 & 0,0 & 0,0 & 0,0 & 0,0 \\
\hline Festucetea vaginatae & 0,0 & 0,0 & 0,0 & 0,0 & 0,0 & 0,0 \\
\hline Festucetalia vaginatae & 0,0 & 0,0 & 0,0 & 0,0 & 0,0 & 0,0 \\
\hline Festucion vaginatae & 0,2 & 0,2 & 0,1 & 0,0 & 0,0 & 0,0 \\
\hline Festucetalia vaginatae s.l. & 0,2 & 0,2 & 0,1 & 0,0 & 0,0 & 0,0 \\
\hline Festucetea vaginatae s.l. & 0,2 & 0,2 & 0,1 & 0,0 & 0,0 & 0,0 \\
\hline Festuco-Brometea & 0,0 & 0,0 & 0,1 & 0,0 & 0,0 & 0,0 \\
\hline Festucetalia valesiacae & 0,0 & 0,0 & 0,0 & 0,0 & 0,0 & 0,0 \\
\hline Festucion rupicolae & 0,0 & 0,0 & 0,0 & 0,0 & 0,0 & 0,0 \\
\hline Cynodonto-Festucenion & 0,0 & 0,1 & 0,0 & 0,0 & 0,0 & 0,0 \\
\hline Festucion rupicolae s.l. & 0,0 & 0,1 & 0,0 & 0,0 & 0,0 & 0,0 \\
\hline Festucetalia valesiacae s.l. & 0,0 & 0,1 & 0,0 & 0,0 & 0,0 & 0,0 \\
\hline Festuco-Brometea s.l. & 0,0 & 0,1 & 0,1 & 0,0 & 0,0 & 0,0 \\
\hline Festuco-Bromea s.l. & 0,2 & 0,3 & 0,2 & 0,0 & 0,0 & 0,0 \\
\hline Chenopodio-Scleranthea & 0,4 & 0,8 & 0,5 & 0,1 & 0,1 & 0,1 \\
\hline Secalietea & 0,5 & 0,4 & 0,4 & 0,1 & 0,0 & 0,1 \\
\hline Oryzetea sativae & 0,0 & 0,0 & 0,0 & 0,0 & 0,0 & 0,0 \\
\hline Oryzetalia & 0,0 & 0,0 & 0,0 & 0,0 & 0,0 & 0,0 \\
\hline Oryzion sativae & 0,1 & 0,5 & 0,0 & 0,0 & 0,3 & 0,0 \\
\hline Oryzetalia s.l. & 0,1 & 0,5 & 0,0 & 0,0 & 0,3 & 0,0 \\
\hline Oryzetea sativae s.l. & 0,1 & 0,5 & 0,0 & 0,0 & 0,3 & 0,0 \\
\hline Chenopodietea & 0,3 & 0,5 & 0,1 & 0,0 & 0,1 & 0,0 \\
\hline Artemisietea & 0,0 & 0,0 & 0,0 & 0,0 & 0,0 & 0,0 \\
\hline Artemisietalia & 0,0 & 0,0 & 0,0 & 0,0 & 0,0 & 0,0 \\
\hline Arction lappae & 0,5 & 0,9 & 0,4 & 0,1 & 0,1 & 0,1 \\
\hline Artemisietalia s.I. & 0,5 & 0,9 & 0,4 & 0,1 & 0,1 & 0,1 \\
\hline Artemisietea s.l. & 0,5 & 0,9 & 0,4 & 0,1 & 0,1 & 0,1 \\
\hline Galio-Urticetea & 0,0 & 0,0 & 0,0 & 0,0 & 0,0 & 0,0 \\
\hline Calystegietalia sepium & 0,0 & 0,0 & 0,0 & 0,0 & 0,0 & 0,0 \\
\hline Galio-Alliarion & 0,8 & 0,8 & 0,6 & 0,1 & 0,1 & 0,1 \\
\hline Calystegion sepium & 2,3 & 3,4 & 2,2 & 0,6 & 1,2 & 0,5 \\
\hline Calystegietalia sepium s.l. & 3,1 & 4,2 & 2,8 & 0,7 & 1,3 & 0,6 \\
\hline Galio-Urticetea s.I. & 3,1 & 4,2 & 2,8 & 0,7 & 1,3 & 0,6 \\
\hline Bidentetea & 0,0 & 0,0 & 0,0 & 0,0 & 0,0 & 0,0 \\
\hline Bidentetalia & 3,1 & 2,3 & 3,6 & 0,6 & 1,0 & 1,9 \\
\hline Bidention tripartiti & 0,5 & 0,7 & 1,1 & 0,1 & 0,3 & 1,3 \\
\hline Chenopodion rubri & 0,0 & 0,0 & 0,1 & 0,0 & 0,0 & 0,0 \\
\hline Bidentetalia s.I. & 3,6 & 3,0 & 4,8 & 0,7 & 1,3 & 3,2 \\
\hline Bidentetea s.l. & 3,6 & 3,0 & 4,8 & 0,7 & 1,3 & 3,2 \\
\hline
\end{tabular}




\begin{tabular}{|l|c|c|c|c|c|c|}
\hline \multirow{2}{*}{ 3/5. táblázat } & \multicolumn{3}{c|}{ Csoportrészesedés } & \multicolumn{3}{c|}{ Csoporttömeg } \\
\cline { 2 - 7 } & Th & Szk & BS & Th & Szk & BS \\
\hline Plantaginetea & 0,0 & 0,0 & 0,0 & 0,0 & 0,0 & 0,0 \\
Plantaginetalia majoris & 1,1 & 0,8 & 0,6 & 0,2 & 0,3 & 0,1 \\
Plantaginetea s.I. & 1,1 & 0,8 & 0,6 & 0,2 & 0,3 & 0,1 \\
Epilobietea angustifolii & 0,0 & 0,0 & 0,0 & 0,0 & 0,0 & 0,0 \\
Epilobietalia & 2,3 & 2,9 & 2,1 & 0,3 & 0,5 & 0,4 \\
Epilobion angustifolii & 0,1 & 0,0 & 0,1 & 0,0 & 0,0 & 0,0 \\
Epilobietalia s.I. & 2,4 & 2,9 & 2,2 & 0,3 & 0,5 & 0,4 \\
Epilobietea angustifolii s.I. & 2,4 & 2,9 & 2,2 & 0,3 & 0,5 & 0,4 \\
Urtico-Sambucetea & 0,0 & 0,0 & 0,0 & 0,0 & 0,0 & 0,0 \\
Sambucetalia & 0,0 & 0,0 & 0,0 & 0,0 & 0,0 & 0,0 \\
Sambuco-Salicion capreae & 0,2 & 0,3 & 0,3 & 0,0 & 0,0 & 0,1 \\
Sambucetalia s.I. & 0,2 & 0,3 & 0,3 & 0,0 & 0,0 & 0,1 \\
Urtico-Sambucetea s.I. & 0,2 & 0,3 & 0,3 & 0,0 & 0,0 & 0,1 \\
Chenopodio-Scleranthea s.I. & 12,2 & 14,3 & 12,1 & 2,2 & 4,0 & 4,7 \\
Indifferens & 3,6 & 3,5 & 3,5 & 1,3 & 1,3 & 0,9 \\
Adventiva & 3,1 & 2,4 & 3,0 & 4,2 & 1,2 & 0,4 \\
\hline
\end{tabular}

Th: Carici elongatae-Alnetum, Tengelici-homokvidék (Kevey - Tóth ined.: 20 felv.) Szk: Carici elongatae-Alnetum, Szigetköz (Kevey - Alexay ined.: 20 felv.)

BS: Carici elongatae-Alnetum, Belső-Somogy (Kevey - Csete ined.: 35 felv.) 
